\title{
Comparative analysis of tests used to assess sperm chromatin integrity and DNA fragmentation
}

\author{
Sulagna Dutta ${ }^{1}$ (D) | Ralf Henkel ${ }^{2,3}$ (I) | Ashok Agarwal ${ }^{3}$
}

${ }^{1}$ Department of Oral Biology and Biomedical Sciences, Faculty of Dentistry, MAHSA

University, Selangor, Malaysia

${ }^{2}$ Department of Medical Bioscience, University of the Western Cape, Bellville, South Africa

${ }^{3}$ American Center for Reproductive Medicine, Cleveland Clinic, Cleveland, $\mathrm{OH}$, USA

Correspondence

Ralf Henkel, Department of Medical Bioscience, University of the Western Cape, Bellville, South Africa.

Email: rhenkel@uwc.ac.za

\begin{abstract}
Male infertility has a complex etiology, and many times, the cause is unknown. While routine semen analysis provides an overview of basic semen parameters, such as sperm concentration, motility, viability and morphology, a significant overlap of these parameters has been reported in fertile and infertile men. Moreover, conventional semen parameters do not reveal the cellular or molecular mechanisms of sperm dysfunctions leading to infertility. Therefore, sperm functional parameters, including sperm chromatin integrity, are evaluated to provide information on subtle sperm defects that are not routinely identified. Incomplete or defective sperm chromatin condensation increases the susceptibility of the sperm DNA to oxidative damage or other factors. To evaluate sperm chromatin integrity, different methods with varying degrees of diagnostic and prognostic capabilities are available. Among these assays, SCSA, TUNEL and SCD assays are most commonly used. While these assays rather evaluate the DNA directly for damages, the aniline blue and chromomycin A3 stains test for the quality of chromatin condensation. Thus, this review discusses and compares different methods used to evaluate sperm chromatin integrity and condensation, and their inclusion in the routine evaluation of the male infertility.
\end{abstract}

\section{KEYWORDS}

ART outcomes, male infertility, oxidative stress, sperm DNA fragmentation, TUNEL assay

\section{1 | BACKGROUND}

Male infertility is assessed and diagnosed primarily with semen analysis according to the guidelines of the World Health Organization (WHO, 2010). Nevertheless, the fertility status of a man cannot be accurately predicted by semen parameters alone (Patel, Leong, \& Ramasamy, 2018). Thus, standard semen analysis is inadequate to conclude if a man is fertile or infertile. Therefore, in order to make a proper clinical diagnosis, it is essential to investigate additional parameters related to sperm functions as these have repeatedly been shown to correlate with the male fertility potential (Barazani, Agarwal, \& Sabanegh, 2014; Franken \& Henkel, 2010). Apart from acrosome reaction or zona pellucida binding ability, other functional tests include sperm DNA integrity and the quality of chromatin condensation. Although the complex DNA of human spermatozoa is tightly packed and well protected in highly compacted chromatin through the exchange of histones by protamines (Ward, 2010), it is still susceptible to insults which can lead to poor DNA integrity and thereby severely impair fertility (Morris, Ilott, Dixon, \& Brison, 2002; Seli, Gardner, Schoolcraft, Moffatt, \& Sakkas, 2004; Simon, Zini, Dyachenko, Ciampi, \& Carrell, 2017).

Incomplete chromatin packaging leaves DNA exposed to reactive oxygen species (ROS), which are recognised as a major cause of sperm DNA damage (Tremellen, 2008). ROS have not only been widely documented as inducing lipid peroxidation of the sperm plasma membrane (Aitken, 1995; Twigg, Fulton, Gomez, Irvine, \& Aitken, 1998), but also as direct cause of sperm DNA fragmentation (SDF) (Bui, Sharma, Henkel, \& Agarwal, 2018). Moreover, end products of lipid peroxidation are not only mutagenic, but also genoand cytotoxic (Esterbauer, 1993; Luczaj \& Skrzydlewska, 2003). 
High SDF levels negatively affect semen quality and reproductive potential. However, these sperm characteristics cannot be identified by the routine semen analysis. Therefore, several tests for SDF and chromatin condensation measurement have been established. Among these, the most common tests for SDF are the terminal deoxynucleotidyl transferase deoxyuridine triphosphate (dUTP) nick end labelling (TUNEL) assay, the sperm chromatin dispersion (SCD) assay, the comet assay and the sperm chromatin structure assay (SCSA) (Majzoub, Esteves, Gosálvez, \& Agarwal, 2016). To evaluate the quality of chromatin condensation, that is the quality of the exchange of histones by protamines as nuclear proteins, the chromomycin A3 (CMA3), toluidine blue (TB) and aniline blue ( $A B)$ stains are most commonly used.

In order to give an overview of the currently available methods and guidelines, this review article critically discusses and compares the methods to test sperm DNA integrity as well as the evidence regarding their efficacy as complementary tests in the workup of male infertility.

\section{1 | Overview of semen analysis and its limitations}

Routine semen analysis remains the cornerstone of laboratory assessment for male infertility as it provides information regarding spermatogenesis, sperm maturation and individual semen components (WHO, 2010). The latest version of the laboratory manual of the World Health Organization ( $5^{\text {th }}$ Edition) suggests lower reference limits based on the $5^{\text {th }}$ percentile and provides information about macro- and microscopic semen characteristics. However, the conventional analysis of semen has limited capacity to determine the underlying changes to molecular and cellular processes that play a crucial role in reproductive functions (Lefievre et al., 2007; Oehninger \& Ombelet, 2019; Patel et al., 2018). In addition, measurement of standard semen parameters does not provide details on specific sperm defects, which can have a major impact on fertility. Thus, more advanced tests that can analyse defects at cellular and molecular levels are required for a more accurate diagnosis (Guzick et al., 2001).

\subsection{Need for testing of sperm chromatin integrity}

\subsection{1 | What added value do sperm chromatin integrity tests provide?}

Considering the significant limitations of conventional semen analysis, other approaches of sperm function testing have been investigated including sperm DNA integrity and chromatin condensation assays (Aitken, 2006; Esteves \& Agarwal, 2011; Lewis, 2013; Oehninger \& Ombelet, 2019; Panner Selvam \& Agarwal, 2018). These tests incorporate the fact that the fertilisation process is a multifactorial process, for which a sequence of different sperm and oocyte functions must be fulfilled (Amann, 1989; Amann \&
Hammerstedt, 1993; Henkel et al., 2005). Sperm DNA should not be damaged during spermatogenesis and spermiogenesis in order to ensure proper embryo development. Hence, tests that can identify the specific cause of sperm dysfunctions can potentially improve diagnostic and management of male infertility, while also alleviating the emotional and financial burden to the patient by the need for extensive repeated tests (Barratt, Mansell, Beaton, Tardif, \& Oxenham, 2011; Hwang, Lipshultz, \& Lamb, 2011).

In this regard, long before increased research efforts were made to investigate the contribution of the DNA integrity, Oehninger et al. (1991) proposed the combination of the hemizona assay and the sperm penetration assay using zona-free hamster oocytes. While the highly predictive value of the hemizona assay has repeatedly been shown (Franken et al., 1989; Vogiatzi et al., 2013), the clinical value of the sperm penetration assay is questionable as it poorly predicts fertilisation outcomes with highly variable predictive values, sensitivity and specificity (Kızılay \& Altay, 2017; Mao \& Grimes, 1988; Oehninger, Franken, Sayed, Barroso, \& Kolm, 2000; Vogiatzi et al., 2013). To make matters worse, both tests are very complex and labour-intensive, and are therefore not practical for routine clinical use.

In this respect, sperm DNA integrity assessment has the highest potential to be included as a complementary test to analyse sperm defects at molecular levels as these tests are easier, quicker and cheaper to perform.

\subsection{2 | What are the current guidelines for testing sperm DNA integrity in patients?}

Despite having strong evidence supporting the vital role of sperm DNA integrity in human reproduction, clinical indications of SDF testing have not yet been established. The effectiveness of the SDF tests in male infertility was assessed in a number of studies, including systematic reviews and meta-analyses in conjunction with various forms of assisted reproduction (IUI, IVF, ICSI) (Cho \& Agarwal, 2017; Cissen et al., 2016; Collins, Barnhart, \& Schlegel, 2008; Deng et al., 2019; Esteves, Agarwal, Cho, \& Majzoub, 2017; Esteves, Roque, Bradley, \& Garrido, 2017; Simon et al., 2010; Simon, Zini et al., 2017; Sugihara, Van Avermaete, Roelant, Punjabi, \& De Neubourg, 2020). According to the latest recommendations of the Practice Committee of the American Society for Reproductive Medicine (2015), SDF may be a cause of poor reproductive performance of couples, but reproductive outcome data (live birth rate) are too limited to recommend routine evaluation of SDF (Practice Committee of the American Society for Reproductive Medicine, 2015). Nonetheless, information about SDF can be clinically informative. These recommendations are based on reports from 2005, 2008 and 2013 (Collins et al., 2008; Greco et al., 2005; Practice Committee of the American Society for Reproductive Medicine, 2013). However, more recent analyses confirm the clinical value of SDF testing (Cho \& Agarwal, 2017; Deng et al., 2019; Esteves, Majzoub, \& Agarwal, 2017a; Esteves, Roque et al., 2017; Simon et al., 2010; Simon, Zini et al., 2017). Recent guidelines of the Society for Translational 
Medicine recommend SDF testing as it may influence the clinical management of patients with high levels of sperm DNA damage (Agarwal, Cho, Majzoub, \& Esteves, 2017c).

Based on these guidelines, SDF testing has been recommended for infertile patients with varicocele, since men with high-grade varicocele often present with normal semen parameters, while impaired semen parameters often correspond with low-grade varicocele (Cho, Esteves, \& Agarwal, 2016; Roque \& Esteves, 2018). SDF testing has also been recommended in cases of unexplained infertility, recurrent failures of in vitro fertilisation (IVF) procedures, repeated miscarriages, exposure to factors or inducers of infertility such as drugs, environmental toxicants, radiation, as well as advanced age, smoking, febrile illness and metabolic syndrome (Agarwal, Majzoub, et al., 2016). Although SDF tests were reported to significantly contribute to the management of infertile men, many renowned reproductive societies, such as the American Society for Reproductive Medicine (ASRM), the American Urological Association (AUA), the European Association of Urology (EAU) and the National Institute of Clinical Excellence (NICE), still do not officially recommend SDF tests as an adjunct to male infertility assessment.

The details of the suggested SDF test guidelines are tabulated in Table 1.
TABLE 1 Clinical practice guidelines for sperm chromatin integrity tests

\section{SDF tests}

Neat semen sample is recommended for SDF testing (grade $\mathrm{C}$ recommendation)

A fixed ejaculatory abstinence before collection of semen sample should be applied (grade $C$ recommendation)

A standardised protocol with stringent quality control is essential for a reliable SDF testing result (grade $\mathrm{B}-\mathrm{C}$ recommendation)

SDF threshold reflects the probability on reproductive outcome (grade $\mathrm{B}-\mathrm{C}$ recommendation)

Indications for SDF testing

Clinical varicocele

SDF testing is recommended in patients with grade $2 / 3$ varicocele with normal conventional semen parameters (grade $\mathrm{C}$ recommendation)

SDF testing is recommended in patients with grade-1 varicocele with borderline/abnormal conventional semen parameter results (grade $\mathrm{C}$ recommendation)

Unexplained infertility/IUI failure/ RPL

SDF testing should be offered to infertile couples with RPL or prior to initiating IUI (grade C recommendation)

Early IVF or ICSI may be an alternative to infertile couple with RPL or failed IUI (grade C recommendation)

IVF and/or ICSI failure

SDF testing is indicated in patients with recurrent failure of assisted reproduction (grade $\mathrm{C}$ recommendation)

The use of testicular spermatozoa rather than ejaculated spermatozoa may be beneficial in men with oligozoospermia, high SDF and recurrent IVF failure (grade $\mathrm{B}-\mathrm{C}$ recommendation)

Borderline abnormal (or normal) semen parameters with risk factor

SDF testing should be offered to patients who have a modifiable lifestyle risk factor of male infertility (grade $\mathrm{C}$ recommendation)

Note: Grades of recommendations according to quality of evidence: Grade A, based on clinical studies of good quality and consistency with at least one randomised trial; Grade B, based on well-designed studies (prospective, cohort) but without good randomised clinical trials; Grade C, based on poorer quality studies (retrospective, case series, expert opinion). Modified from Oxford Centre for Evidence-Based Medicine (http://www.cebm.net/oxford-centre-evidence-based-medic ine-levels-evidence-march-2009/). SDF, sperm DNA fragmentation; IUI, intrauterine insemination; RPL, recurrent pregnancy loss; IVF, in vitro fertilisation; ICSI, intracytoplasmic sperm injection. 
TABLE 2 Comparison of sperm chromatin integrity tests

\begin{tabular}{|c|c|c|c|}
\hline Test & Principle & Advantage & Disadvantage \\
\hline SCD or Halo test & $\begin{array}{l}\text { Assesses dispersion of DNA fragments } \\
\text { after denaturation. Uses optical and } \\
\text { fluorescence microscopy }\end{array}$ & Simple test & Inter-observer variability \\
\hline Comet assay & $\begin{array}{l}\text { Electrophoretic assessment of DNA } \\
\text { fragments of lysed DNA. Uses fluorescence } \\
\text { microscopy }\end{array}$ & $\begin{array}{l}\text { Can be done in samples with very } \\
\text { low sperm count. It is sensitive and } \\
\text { reproducible }\end{array}$ & $\begin{array}{l}\text { Requires an experienced } \\
\text { observer. Inter-observer } \\
\text { variability }\end{array}$ \\
\hline SCSA & $\begin{array}{l}\text { Measures the susceptibility of sperm DNA } \\
\text { to denaturation. The test is the flow } \\
\text { cytometric version of AO test. Uses flow } \\
\text { cytometry }\end{array}$ & $\begin{array}{l}\text { Reliable estimate of the percentage of } \\
\text { DNA-damaged spermatozoa }\end{array}$ & $\begin{array}{l}\text { Requires expensive } \\
\text { instrumentation (flow } \\
\text { cytometer) and high-skilled } \\
\text { technicians }\end{array}$ \\
\hline CMA3 staining & $\begin{array}{l}\text { CMA3 competitively binds to DNA indirectly } \\
\text { visualizing protamine-deficient DNA. Uses } \\
\text { fluorescence microscopy }\end{array}$ & $\begin{array}{l}\text { Yields reliable results as it is strongly } \\
\text { correlated with other assays }\end{array}$ & Inter-observer variability \\
\hline TB staining & $\begin{array}{l}\text { Increased affinity of TB to sperm DNA } \\
\text { phosphate residues. Uses optical } \\
\text { microscopy }\end{array}$ & Rapid, simple and inexpensive & Inter-observer variability \\
\hline $\mathrm{AB}$ staining & $\begin{array}{l}\text { Increased affinity of AB dye to lose } \\
\text { chromatin of sperm nucleus. Uses optical } \\
\text { microscopy }\end{array}$ & Rapid, simple and inexpensive & $\begin{array}{l}\text { Inter-laboratory variations and } \\
\text { lack of reproducibility }\end{array}$ \\
\hline
\end{tabular}

\section{2 | CAUSES AND CONSEQUENCES OF IMPAIRED SPERM DNA INTEGRITY}

During the process of spermatogenesis, sperm DNA is intricately condensed and compactly assembled to protect itself from damage. In somatic cells, DNA is draped around histone proteins, while in spermatozoa they are mostly replaced by basic protamines, which ensure a proper condensation (Fuentes-Mascorro, Serrano, \& Rosado, 2000; Poccia, 1986), preventing the sperm DNA from undergoing transcriptions and translations (Henkel \& Franken, 2011). Protamines are small, highly basic proteins with a high content of cysteine (Krawetz \& Dixon, 1988) and allow the DNA to be at least 6 times more condensed than in mitotic chromosomes (Fuentes-Mascorro et al., 2000). This highly compacted chromatin structure in spermatozoa is essential for male fertility as it ensures that the male genome is protected against major insults. Restructuring and rearrangement of the male genome is not easy and problems from torsional stress to the molecule by negative supercoiling can cause problems with the transition from histones to protamines (Balhorn, 1982; McPherson \& Longo, 1993). In order to relief this torsional stress, transient DNA double-strand breaks with subsequent resealing take place (Marcon \& Boissonneault, 2004; McPherson \& Longo, 1992). This supports chromatin rearrangement during displacement of histones by protamines (Chen \& Longo, 1996; Hirano, 2002; McPherson \& Longo, 1992; Zhao et al., 2004). McPherson and Longo (1992) postulated that chromatin packaging requires the enzyme topoisomerase
II to create and ligate nicks in order to facilitate protamination during spermiogenesis. Failure to exchange histones against protamines during sperm chromatin compaction results not only in poor quality of the chromatin package, but is also closely associated with sperm DNA damage (Manochantr, Chiamchanya, \& Sobhon, 2012; Tarozzi et al., 2009), and an incorrect DNA rearrangement may lead to severe DNA damage during the process of protamination (Aoki, Liu, \& Carrell, 2005). Consequently, endogenous nicks in ejaculated spermatozoa are indicative for incomplete maturation of spermatozoa during spermiogenesis, resulting in a disturbed chromatin condensation due to an under-protamination. In addition, defects in the generation of disulphide cross links between protamines make spermatozoa more prone to ROS-induced damage and cause a higher rate of SDF (Steele, McClure, Maxwell, \& Lewis, 1999).

ROS are major causes of sperm DNA damage (Agarwal \& Sengupta, 2020). ROS affect spermatozoa mainly during the transit through the epididymis where they enhance endonuclease and caspases activities, resulting in an increasing rate of germ cell apoptosis (Sakkas \& Alvarez, 2010). In this process, pro-apoptotic factors such as BAX or BAD lead to mitochondrial membrane leakage of cytochrome $C$, thereby activating the intrinsic apoptotic cascades (Shaha, Tripathi, \& Mishra, 2010; Steele et al., 1999). Moreover, the Fas receptors on the sperm membrane can activate the extrinsic apoptotic pathway (Agarwal \& Said, 2003) by binding to Fas ligand expressed on Sertoli cells' membrane (Lee, Richburg, Younkin, \& Boekelheide, 1997). The Fas receptors were found to be expressed 
in $10 \%$ of infertile men with normozoospermia and $50 \%$ with oligozoospermia (Sakkas et al., 1998).

Various other etiologic considerations of sperm DNA damage include exposure to toxins, lifestyle issues (smoking, obesity), replication defects, UV rays, and ionising and non-ionising radiation (Durairajanayagam, 2018; Henkel, 2018; Leisegang \& Dutta, 2020; Rehman, Ahmad, \& Alshahrani, 2018). Both, single-stranded (ssDNA) and double-stranded (dsDNA) DNA breaks can occur. dsDNA fragmentation is irreversible and are localised at the nuclear matrix with only a few break points. It is conceivable that this type of DNA fragmentation is associated with a lack of DNA repair during meiosis. They can impact on fertilisation and embryonic development, especially after ICSI (Casanovas et al., 2019; Ribas-Maynou \& Benet, 2019). In contrast, ssDNA breaks are found in all regions of the DNA, are related to oxidative stress and associated with pregnancy failure using IVF (Simon et al., 2013).

Sperm DNA damage is associated with altered semen parameters, recurrent miscarriages and impaired fertility outcomes both natural and following ARTs as well as the risk of genetic or birth defects (Borges et al., 2019; Deng et al., 2019; Johnson, Dunleavy, Gemmell, \& Nakagawa, 2015; Venkatesh et al., 2011; Zini, 2011).

\section{3 | SPERM CHROMATIN INTEGRITY TESTS}

Several methods for the determination of sperm DNA damage are available, such as the TUNEL, SCD, comet and SCSA assays, as well as the determination of 8-hydroxy-2-deoxyguanosine (8-OHdG). To determine the quality of sperm chromatin condensation, staining techniques based on CMA3, toluidine blue and aniline blue, are used and described below (Table 2).

\section{1 | Terminal deoxynucleotidyl transferase dUTP nick end labelling (TUNEL) assay}

In this assay, single- and double-stranded DNA breaks are both labelled with fluorescein-thiocyanate (FITC)-dUTP in a single step staining method before the sample undergoes fluorescence microscopic or flow cytometric analysis. In the TUNEL assay, a template-independent DNA polymerase, the terminal deoxynucleotidyl transferase (TdT), adds the FITC-dUTP label to the nicks at the $3^{\prime}$ hydroxyl end of the DNA (Sharma, Ahmad, Esteves, \& Agarwal, 2016). Thus, if there are more nicks in the DNA, more FITC-dUTP will be bound resulting in more cells fluorescing with a stronger fluorescent signal, which is then observed in a fluorescent microscope or measured by flow cytometry (Sharma et al., 2016).

There are several commercial kits for the TUNEL assay on the market. Generally, these kits comprise a reaction buffer, TdT, FITCdUTP and propidium iodide/RNase (PI/RNase) stain. For the flow cytometric method, paraformaldehyde (3.7\%) is used to fix approximately $2.5 \times 10^{6}$ spermatozoa for $30 \mathrm{~min}$ at $4^{\circ} \mathrm{C}$. Then, the sample is centrifuged at $300 \mathrm{~g}$ for $7 \mathrm{~min}$, the supernatant is discarded and the pellet resuspended with $1 \mathrm{ml}$ ice-cold ethanol (70\% v/v). Sample tubes can then be stored at $-20^{\circ} \mathrm{C}$. Negative controls are prepared by not adding the enzyme $\mathrm{TdT}$ to the reaction mixture, while the positive sperm controls are prepared by pre-treating the samples with $2 \%(\mathrm{v} / \mathrm{v})$ hydrogen peroxide for $1 \mathrm{hr}$ at $50^{\circ} \mathrm{C}$, in order to actively damage sperm DNA. The sample $(50 \mu \mathrm{l})$ is then stained for $1 \mathrm{hr}$ by incubating them in the reaction mix, followed by $\mathrm{PI} / \mathrm{RNase}$ staining for $30 \mathrm{~min}$. Laser excitation for flow cytometry is given by a solid blue laser at 2 wavelengths of $488 \mathrm{~nm}$ powered by $20 \mathrm{~mW}$ and of $640 \mathrm{~nm}$ by $14.7 \mathrm{~mW}$ diode red laser, respectively. The FL-1 channel measures the green fluorescence (480-530 nm), while red fluorescence $(640 \mathrm{~nm})$ is measured in the FL-2 channel. Finally, the percentage of TUNEL-positive cells is calculated using the flow cytometer software.

The sensitivity of SDF measurement using the standard TUNEL assay can be significantly increased by incubating samples in $2 \mathrm{mM}$ dithiothreitol (DTT) solution for $45 \mathrm{~min}$, followed by formaldehyde fixation. The TUNEL assay protocol was also modified by Mitchell et al. where spermatozoa were incubated with 'LIVE/DEAD Fixable Dead Cell Stain' (far red) (Molecular Probes) for $30 \mathrm{~min}$ at $37^{\circ} \mathrm{C}$ to simultaneously assess both DNA integrity and vitality (Mitchell, De Iuliis, \& Aitken, 2011). Due to the covalent binding between the dye and the amines, this staining is very stable and is not washed out during the TUNEL process. Subsequently, cells are washed three times with culture medium, followed by an additional incubation with DTT to allow simultaneous assessment of both DNA integrity and vitality.

Male infertility laboratories widely use the TUNEL assay for measuring SDF (Baskaran et al., 2019) as it is considered the 'gold standard' for SDF testing. The percentage of spermatozoa with fragmented DNA negatively correlates with sperm morphology, motility and concentration (Carrell et al., 2003; Zini, Bielecki, Phang, \& Zenzes, 2001). Furthermore, in an ART setting, SDF can be used as predictor of reproductive outcomes, including fertilization rate in ICSI, pregnancy rate following IUI and IVF and embryo cleavage rate (Benchaib et al., 2003; Duran, Morshedi, Taylor, \& Oehninger, 2002; Henkel et al., 2004; Siddhartha et al., 2019; Simon, Zini et al., 2017; Sun, Jurisicova, \& Casper, 1997). It provides a scientific understanding of the underlying cause in case of recurrent pregnancy loss (Opuwari, Henkel, \& Agarwal, 2019). The predictive threshold of the TUNEL assay with a good to high predictive power depends on the methodology and specific protocol used, with cut-off values varying between 20\% and 36\% (Benchaib et al., 2003; Henkel et al., 2004; Sergerie, Laforest, Bujan, Bissonnette, \& Bleau, 2005). The high specificity of the TUNEL assay aids in the identification of the underlying cause of the infertility in infertile men without SDF (Sharma et al., 2010, 2016). On the other hand, its high positive predictive value helps to confirm that infertile men with positive TUNEL result truly have abnormal SDF that may be the cause of their infertility (Cui et al., 2015).

As any method, the TUNEL assay has its advantages and disadvantages. Generally, the TUNEL assay procedure is time-consuming and labour-intensive, particularly when fluorescence microscopy is 
used. In this case, the number of cells that are evaluated (100-200) is relatively low. In contrast, flow cytometry is widely automated, and 10,000 cells can be measured in a short period of time resulting in a higher accuracy. On the other hand, a flow cytometer is expensive and can be cost prohibitive for many laboratories. Results are also significantly influenced by the type of fixation used, incubation time and the fluorochrome used to label fragmented DNA (Muratori et al., 2010). For a bench-top flow cytometer, relatively good quality control parameters with small inter- and intra-observer variations were demonstrated $(<8 \%)$ which makes this a good option in smaller laboratories where there may not be a single well-trained person who performs the test (Ribeiro et al., 2017; Sharma et al., 2010).

\subsection{Sperm chromatin dispersion test (Halosperm assay)}

The sperm chromatin dispersion (SCD) test analyses the formation of halos resulting from the release of DNA loops after denaturation. These halos arise after treating sperm samples in an agarose gel with an acid solution and lysis buffer. A small or even no halo is produced if the sperm DNA is fragmented. On the contrary, if the DNA is intact, a distinct halo is generated by the DNA looping out (Fernández et al., 2003). The halos can then be observed using a bright field or fluorescence microscope (Fernández et al., 2005).

For the SCD test, sperm aliquots are diluted with PBS to a sperm concentration of 5-10 million/ml. An aliquot of this mixture is then mixed with aqueous agarose $(0.65 \%$ standard agarose dissolved in PBS at $80^{\circ} \mathrm{C}$ ), and $50 \mu \mathrm{l}$ are added on a glass slide, covered using a glass coverslip and kept undisturbed horizontally for $4 \mathrm{~min}$ to solidify at $4^{\circ} \mathrm{C}$. For denaturation, slides are immersed in freshly prepared $0.08 \mathrm{~N} \mathrm{HCl}$ for $7 \mathrm{~min}$ at $22^{\circ} \mathrm{C}$ in dark. Subsequently, slides are transferred to a tray containing a solution $(0.4 \mathrm{~mol} / \mathrm{L}$ Tris, $0.8 \mathrm{~mol} / \mathrm{L}$ DTT, $1 \% \mathrm{SDS}$ and $50 \mathrm{mmol} / \mathrm{L}$ EDTA, $\mathrm{pH}$ 7.5) for neutralizing and lysing the proteins for $10 \mathrm{~min}$ at room temperature. This is followed by 5 -min incubation in another neutralizing and lysing solution $(0.4 \mathrm{~mol} / \mathrm{L}$ Tris, $2 \mathrm{~mol} / \mathrm{L} \mathrm{NaCl}$ and $1 \% \mathrm{SDS}, \mathrm{pH}$ 7.5) at room temperature. Afterwards, slides are carefully washed for $2 \mathrm{~min}$ in Tris-borate EDTA buffer (0.09 mol/L Tris-borate and $0.002 \mathrm{~mol} / \mathrm{L}$ EDTA, pH 7.5), dehydrated in increasing concentrations of ethanol and finally air-dried. For the evaluation in a bright field microscope, slides are stained with Wright's staining solution and the halos evaluated. In the newer improved version of the SCD test (Halosperm ${ }^{\circledR}$ kit) for use under a fluorescence microscope, slides are stained with $2 \mu \mathrm{g} / \mathrm{ml}$ of DAPI (4',6-diamidino-2-phenylindole) (Fernández et al., 2003).

The advantages of the SCD test are that it is fast, the proto$\mathrm{col}$ is easy to perform and results are moderately, but significantly correlated to SCSA and TUNEL ( $r=.70$ and $r=.66$, respectively) (Javed, Talkad, \& Ramaiah, 2019; Zhang et al., 2010). This test is also cost-effective as the protocol supports the use of bright field microscopy and has also successfully been used in clinical studies with good predictive power for fertilization and pregnancy after IVF and ICSI (Anifandis et al., 2015; Meseguer et al., 2009; Tandara et al., 2014). The test can also be combined with the simultaneous evaluation of 8-oxoguanine levels, a marker for oxidative DNA damage (Kasai, 1997) by using specific DNA probes (Santiso et al., 2010). Results showed higher levels of 8-oxoguanine in spermatozoa with fragmented DNA, indicating a clear association between these two types of DNA damage. Clinically, the SCD test correlates negatively with ART outcomes, including rates of fertilization and embryo quality, but the result did not show any association with rates of clinical pregnancy or live births (Muriel, Garrido et al., 2006; Muriel, Meseguer et al., 2006; Sun et al., 2018; Velez de la Calle et al., 2008). A meta-analysis by Cissen et al. indicated that the SCD test has poor predictive value for positive assisted reproductive outcome (Cissen et al., 2016).

\section{3 | Comet assay}

The comet assay, also known as the single-cell gel electrophoresis, applies basic principles of permeability and electrophoretic movement of fragmented DNA. The characteristic 'comet' appearance is from the stained unwound DNA fragments that form a tail after electrophoretic movement in the agarose gel and gives the test its unique name. Unfragmented DNA, on the other hand, remains in the comet head. It quantifies DNA damage via measurement of displacement between the nuclear genetic material (comet head) and the migrated unwound DNA tail. The length of this tail serves as an index of sperm DNA damage (Simon, Aston, Emery, Hotaling, \& Carrell, 2017). The 'tail moment' or torsional moment of the tail is obtained by multiplying tail length with the fraction of the total DNA in the tails (Hellman, Vaghef, \& Boström, 1995) when visualised using a fluorescent DNA binding dye. The test can be carried out under neutral and alkaline $\mathrm{pH}$ conditions. In the neutral comet assay, dsDNA loops migrate as unwound tail from the loosened supercoiled nucleus of damaged cells and the level of DNA unwinding is proportional to the degree of cellular damage (van Kooij et al., 2004). While under neutral $\mathrm{pH}$ conditions only dsDNA strand breaks will be determined, the use of alkaline electrophoresis buffer exposes the alkali-labile DNA sites (Simon, Aston et al., 2017) and makes it possible to detect both, ssDNA and dsDNA strand breaks. This procedure increases the test sensitivity, whereas the modified two-tailed comet assay (2T-Comet) can detect ssDNA and dsDNA simultaneously (Cortés-Gutiérrez, Fernández, Dávila-Rodríguez, López-Fernández, \& Gosálvez, 2017; Singh et al., 1989). Most SDF tests fail to simultaneously detect and differentiate between ssDNA and dsDNA breaks in the same spermatozoon, while the $2 \mathrm{~T}$-Comet represents an exception.

The comet assay can effectively evaluate sperm DNA damage after cryopreservation (Duty et al., 2002) and its results predict embryo development following ARTs, mainly in cases of unexplained infertility (Javed et al., 2019; Morris et al., 2002; Simon et al., 2010; Tomsu, Sharma, \& Miller, 2002). Despite the establishment of clinical thresholds for diagnostic purposes (Lewis \& Agbaje, 2008; Lewis \& Simon, 2010; Shamsi et al., 2010; Simon, Lutton, McManus, \& Lewis, 2011; Simon, Zini et al., 2017), this test is a convenient, 
sensitive, fast and versatile assay for the quantification and characterization of sperm DNA damage (Enciso, Sarasa, Agarwal, Fernández, \& Gosálvez, 2009; Simon, Zini et al., 2017). However, this assay demands a high level of expertise for interpretation of the results based on observations under fluorescence microscopy.

\section{4 | Measurement of 8-hydroxy-2-deoxyguanosine (8-OHdG)}

8-hydroxy-2-deoxyguanosine (8-OHdG) is a by-product of oxidative damage of sperm DNA and a measure of cellular oxidative damage. Owing to its potent mutagenicity, $8-\mathrm{OHdG}$ is the most widely studied marker for oxidative DNA damage (Shen \& Ong, 2000).

This assay uses a three-step protocol. In step 1, the sperm DNA extraction step, the cells are washed $(10 \mathrm{mmol} / \mathrm{L}$ Tris $-\mathrm{HCl}, 10 \mathrm{mmol} / \mathrm{L}$ EDTA, $1 \mathrm{~mol} / \mathrm{L} \mathrm{NaCl}, \mathrm{pH} 7.0$ ) and lysed (0.9\% SDS, $0.5 \mathrm{mg} / \mathrm{ml}$ proteinase $\mathrm{K}$ and $0.04 \mathrm{~mol} / \mathrm{L}$ DTT) for $1 \mathrm{hr}$ at $55^{\circ} \mathrm{C}$. Sperm DNA extraction is then mediated by chloroform-isoamyl alcohol $(12: 1 \mathrm{v} / \mathrm{v})$. Following RNA removal with ribonuclease $A$, the extracted sperm DNA is digested by dissolving in $10 \mathrm{mmol} / \mathrm{L}$ Tris- $\mathrm{HCl}(\mathrm{pH}$ 7.0). In step 2, DNA is enzymatically digested using three enzymes: DNase I, nuclease P1 and alkaline phosphatase. Subsequently, the resultant solution is dried at low temperature and pressure and the sample re-dissolved in deionised distilled water. In Step 3, the sample is analysed using high-pressure liquid chromatography (HPLC). Standard 8-OHdG is used to calibrate the curve for $8-\mathrm{OHdG}$, and results are reported as $8-\mathrm{OHdG} / 10^{4} \mathrm{dG}$ (Kodama, Yamaguchi, Fukuda, Kasai, \& Tanaka, 1997). Alternatively, the detection of 8-OHdG can also be done using immunofluorescent techniques such as fluorescence microscopy or flow cytometry (Cambi et al., 2013).

The 8-OHdG assay can successfully distinguish between fertile and infertile men (Kodama et al., 1997), and the results have been shown to positively correlate with SDF assessed by TUNEL assay (Aitken, De luliis, Finnie, Hedges, \& McLachlan, 2010) as well as with impaired sperm chromatin remodelling (De luliis et al., 2009). The levels of 8-OHdG are reportedly higher in smokers and in infertile patients with varicocele (Ishikawa, Fujioka, Ishimura, Takenaka, \& Fujisawa, 2007). Due to its potent mutagenicity, higher levels of 8-OHdG have been associated with miscarriages, foetal malformations or even childhood malignancy (Agarwal, Varghese, \& Sharma, 2009; Loft \& Poulsen, 1996).

\section{5 | Acridine orange}

Acridine orange $(\mathrm{AO})$ is a fluorochrome that measures the susceptibility to denaturation of sperm nuclear DNA. This dye intercalates as a monomer in dsDNA and binds as a whole to ssDNA: depending on the type of DNA, a metachromatic shift is observed from green, indicating native supercoiled DNA (dsDNA), to red fluorescence, indicating relaxed-coiled or denatured DNA (ssDNA), if the DNA is fragmented (Hoshi, Katayose, Yanagida, Kimura, \& Sato, 1996). The
AO test was initially developed as a fluorescence microscopy-based test by Tejada, Mitchell, Norman, Marik, and Friedman (1984).

The semen sample is smeared on a glass slide and fixed with Carnoy's fixative (methanol: acetic acid; 1:3) for $2 \mathrm{hr}$, followed by staining for $5 \mathrm{~min}(0.19 \mathrm{mg} / \mathrm{ml} \mathrm{AO}$ in $0.08 \mathrm{M}$ citric acid, $12 \mathrm{mM}$ $\mathrm{Na}_{2} \mathrm{HPO}_{4}, \mathrm{pH} 2.5$ ) at room temperature. Stock solutions are stored in the dark at $4^{\circ} \mathrm{C}$, with the working $\mathrm{AO}$ staining solution being prepared daily. After the staining, the slides are rinsed with deionised water, and then examined in a fluorescence microscope and the ratio of (red)/(green + red) fluorescing spermatozoa calculated as DNA fragmentation index (DFI).

Studies show that infertile men have a significantly higher percentage of AO-positive spermatozoa than fertile controls and that men with varicocele have significantly more AO-positive spermatozoa than the infertile group (Talebi, Moein, Tab ibnejad, \& Ghasemzadeh, 2008). Varicocelectomy resulted in a significant improvement in DNA integrity, thus demonstrating the clinical utility of the AO stain (Zini, Blumenfeld, Libman, \& Willis, 2005). Staining of ssDNA is also inversely associated with successful IVF and pregnancy outcomes (Hoshi et al., 1996; Katayose, Yanagida, Hashimoto, Yamada, \& Sato, 2003; Virant-Klun, Tomazevic, \& Meden-Vrtovec, 2002).

\subsection{Sperm chromatin structure assay (SCSA)}

The SCSA is also based on the metachromatic properties of $A O$ and is a flow cytometric adaptation of the fluorescence microscopic $A O$ test. This assay was developed and then further evaluated and standardised by Evenson, Darzynkiewicz, and Melamed (1980), Evenson et al. (1999), Evenson (2016), Virro, Larson-Cook, and Evenson (2004) and Evenson and Wixon (2006) in the 1980s and 1990s.

For this assay, a semen sample (about 13-70 $\mu \mathrm{l}$ ) is diluted with TNE buffer (0.01 M Tris- $\mathrm{HCl}, 0.15 \mathrm{M} \mathrm{NaCl}$ and $1 \mathrm{mM}$ EDTA, $\mathrm{pH} 7.4$ ) to attain a concentration of $1-2 \times 10^{6} \mathrm{spermatozoa} / \mathrm{ml}$. An acid detergent solution $(\mathrm{pH}=1.2)(0.1 \%$ Triton $X-100,0.08 \mathrm{~N} \mathrm{HCl}, 0.15 \mathrm{~mol} / \mathrm{L}$ $\mathrm{NaCl}$ ) is then added to the sperm suspension for $30 \mathrm{~s}$, followed by staining with $6 \mathrm{mg} / \mathrm{L}$ purified $\mathrm{AO}$ (in phosphate-citrate buffer, $\mathrm{pH}$ 6.0). Flow cytometric analysis of the stained sample is then performed (Evenson et al., 1999), and the levels of DNA fragmentation are measured as DFI.

Due to the fact that the SCSA is a standardised assay with a fixed protocol and its results are consistent over a long period of time, the SCSA is widely used by many reproductive medicine units in the andrological workup of male infertility. It has been suggested that a DFI threshold of $<30 \%$ in semen samples of a subject may not only indicate the potential of initiating in vivo pregnancy (Evenson \& Wixon, 2006; Giwercman et al., 2010; Virro et al., 2004), but also for fertilization and implantation rates in IVF (Bungum et al., 2007; Miciński, Pawlicki, Wielgus, Bochenek, \& Tworkowska, 2009; Virro et al., 2004). On the other hand, a number of meta-analyses and systematic reviews could not find a predictive value in the determination of the DFI by means of the SCSA, neither in IVF nor in ICSI (Collins et al., 2008; Li, Wang, Cai, \& Huang, 2006; Simon, Zini 
et al., 2017). Although the DFI as determined with the SCSA is a promising test to determine sperm DNA damage in male infertility with clinical threshold already established, it is also criticised as it determines the DNA damage after denaturation of the DNA; thus, it determines the susceptibility of the DNA to damage (Henkel, 2007; Tarlatzis \& Goulis, 2010). In addition, the method needs expensive instrumentation (flow cytometer) and demands high technical skills.

\section{7 | Chromomycin A3 (CMA3) assay}

CMA3 is an anthraquinone glycoside produced by a specific strain of the bacterium Streptomyces griseus that, in the presence of $\mathrm{Mg}^{2+}$ binds to DNA, where it specifically competes for the protamine binding sites through the minor groove of the DNA, thus indicating protamine deficiency in CMA3-positive spermatozoa (Bianchi, Manicardi, Bizzaro, Bianchi, \& Sakkas, 1993; Kamiyama, 1968; Lolis et al., 1996).

An air-dried sperm sample is fixed on a glass slide with methanol-glacial acetic acid $(3: 1, \mathrm{v} / \mathrm{v})$ at $4^{\circ} \mathrm{C}$ for $20 \mathrm{~min}$ and then treated with CMA3 solution (in Mcllvaine's buffer with $10 \mathrm{mmol} / \mathrm{L} \mathrm{MgCl}_{2}$ ) for $20 \mathrm{~min}$. This is followed by rinsing the slide with buffer and then mounting with PBS-glycerol $(1: 1, v / v)$. At least 200 spermatozoa on each slide are evaluated using a fluorescence microscope. CMA3-positive spermatozoa (stained bright yellow or bright green) indicate inadequate DNA protamination, whereas CMA3-negative spermatozoa (staining faint yellow or dull green) indicate high DNA protamination (Kazerooni et al., 2009; Manicardi et al., 1995; Zini et al., 2002). CMA3 results negatively correlate with sperm morphology and also with sperm motility and concentration (Franco et al., 2012; Manochantr et al., 2012). In addition, this technique is a potent predictor of IVF outcomes (Esterhuizen, Franken, Lourens, Prinsloo, \& Van Rooyen, 2000; Sakkas et al., 1998). The main limitation of this assay lies in inter-observer subjectivity and the fact that only a relatively small number of spermatozoa can be evaluated.

\section{8 | Toluidine blue (TB) staining}

Toluidine blue is a basic thiazine metachromatic dye that specifically binds to acidic cellular components of the tissue. This dye displays high affinity for binding to the phosphate residue of immature sperm DNA (Erenpreisa et al., 2003; Marchesi, Biederman, Ferrara, Hershlag, \& Feng, 2010). The method includes fixation of air-dried sperm smears on a slide using $96 \%$ ethanol-acetone $(1: 1)$ at $4^{\circ} \mathrm{C}$ for $30 \mathrm{~min}$, followed by hydrolysis using $0.1 \mathrm{~N} \mathrm{HCl}$ at $4^{\circ} \mathrm{C}$ for 5 min. Slides are then rinsed three times for 2 min. in distilled water. TB (0.05\%) (in 50\% Mcllvain buffer, $\mathrm{pH}$ 3.5) is used to stain the smears for $5 \mathrm{~min}$. Subsequently, slides are briefly rinsed with distilled water, blotted on filter paper and dehydrated twice in tertiary butanol for $3 \mathrm{~min}$, followed by xylene treatment. Finally, slides can be mounted and evaluated using a light microscope. Sperm heads with normal DNA integrity are stained light blue, while those sperm heads with damaged DNA are stained violet (Erenpreiss, Bars, Lipatnikova, Erenpreisa, \& Zalkalns, 2001).
Toluidine blue staining finds applicability in male fertility assessment, as the method has a specificity of $95 \%$ and a sensitivity of $42 \%$ at a threshold of 45\% (Talebi et al., 2008; Tsarev et al., 2009). The method is simple and uses common cost-effective stains. The results also correlate with advanced tests like SCSA and TUNEL used to ascertain SDF (Erenpreiss et al., 2004; Shamsi, Imam, \& Dada, 2011).

\section{9 | Aniline blue (AB) staining}

Aniline blue is used to determine chromatin condensation by using an acidic dye with high affinity for lysine-rich histones that are not exchanged by protamines during spermatogenesis. Cysteine/arginine-rich protamines do not stain with $A B$. Hence, like with CMA3, this method identifies under-protaminated immature spermatozoa, as they contain high levels of histones. The staining method was first described by Terquem and Dadoune (1983).

A smear of semen is prepared on a slide, air-dried and fixed for 30 min in 3\% glutaraldehyde in PBS. Then, it is stained in 5\% aqueous acidic $(\mathrm{pH} 3.5) \mathrm{AB}$ solution for $5 \mathrm{~min}$. Excessive stain is washed off under running water and the slides blotted on filter paper. After drying, slides can be mounted. Slides are evaluated using a bright field microscope, a total of 200 spermatozoa are counted and the percentage of aniline blue-positive spermatozoa is calculated. The protocol is simple and requires inexpensive equipment. However, the staining is not always homogenous and can be influenced by the presence of seminal plasma. Therefore, prior washing of the spermatozoa with PBS is often recommended.

Reported cut-off values for fertilisation, cleavage and pregnancy rates vary between $20 \%$ (Hammadeh, Stieber, Haidl, \& Schmidt, 1998) and $28 \%$ (Haidl \& Schill, 1994) aniline blue-positive spermatozoa for IVF and 29\% aniline blue-positive spermatozoa for ICSI (Hammadeh et al., 1996). Infertile patients show a high percentage of spermatozoa with decondensed and unstable nuclear content (Foresta, Zorzi, Rossato, \& Varotto, 1992). However, correlation of these test results with individual sperm parameters is controversial, since blue staining has also been reported in association with normal sperm parameters (Dadoune, Mayaux, \& Guihard-Moscato, 1988; Kazerooni et al., 2009; Kim et al., 2013). In asthenozoospermic samples, immature chromatin may or may not be associated with abnormal morphological patterns (Hammadeh et al., 2001; Kodama et al., 1997), while chromatin condensation levels as determined via $A B$ staining can serve as potential predictor of IVF outcomes (Foresta et al., 1992; Wong et al., 2008).

\section{4 | CURRENT CHALLENGES IN SPERM CHROMATIN INTEGRITY TESTING}

\section{1 | Limitations of current protocols}

The lack of standardization of any chromatin integrity test is one of the primary limitations of SDF tests (Esteves, Agarwal, \& Majzoub, 2017). Consequently, there is no international agreement 
on which test is preferred. Moreover, depending on the methodology, some SDF assays show a high degree of inter-individual and inter-laboratory variability. This requires revalidation even when using updated equipment (Sharma, Gupta, Henkel, \& Agarwal, 2019). It is further mandatory to conduct these tests at laboratories with suitable equipment, trained technicians as well as internal and external quality control procedures in place (Esteves, Roque et al., 2017).

There is also a principal difference between two major groups of chromatin integrity tests that often causes confusion, (a) tests for chromatin condensation and (b) tests for DNA damage. Tests for chromatin condensation such as the aniline blue, toluidine blue and chromomycin A3 stains evaluate the quality of the packaging and condensation of the DNA due to the exchange of histones as nuclear proteins by protamines; tests for DNA damage measure the DNA damage more directly. These DNA damage tests have to again be separated into two groups: (a) tests measuring a DNA damage and (b) tests measuring potential, that is secondary signs, of DNA damage. While 8-OHdG testing, TUNEL assay and the comet assay under neutral $\mathrm{pH}$ conditions belong to the former group, the latter group comprises the SCSA, SCD test and the comet assay under alkaline $\mathrm{pH}$ conditions (Henkel, 2007). Furthermore, it is important to differentiate between direct damages to the DNA such as DNA fragmentation or DNA strand breakages, abasic sites, base modifications, DNA-DNA cross links or DNA-protein cross links (Aitken, De luliis, \& McLachlan, 2009). Each of these different types of DNA damage would have to be determined by a different assay. Yet, only DNA strand breakages/fragmentations are commonly referred to as DNA damage and are usually tested for. Nevertheless, the other DNA damages such as abasic sites or base modifications do not have less biological and clinical importance (Aitken et al., 2009). Due to these differences, it is challenging to correlate the results obtained from different individual tests (Esteves, Sharma, Gosálvez, \& Agarwal, 2014; Feijó \& Esteves, 2014). Also, SDF testing methods fail to detect the exact nature and location of sperm DNA damage (Esteves, Agarwal et al., 2017). Apart from the fact that there is no universally agreed upon test, methodology or protocol, different cut-off values for SDF tests have been proposed, but can only be compared to a limited extent.

\subsection{Controversies of sperm DNA fragmentation and its predictive value}

There are several limitations which limit the ability of SDF screening to be recommended in case of patients with unexplained infertility, repeated pregnancy loss and poor ART outcomes (Esteves, Roque et al., 2017), despite the fact that sperm DNA damage is common in men with infertility.

Sharma et al. (Sharma et al., 2016) had put forth a detailed protocol and quality control measurements of the SDF testing using the TUNEL assay in a study including 95 controls and 261 samples from infertile men. In the study, the positive predictive value was recorded as $91.4 \%$ and negative predictive value was $33.1 \%$. Thus, it establishes that elevated SDF levels in men can possibly lead to fertility impairments. Wiweko and Utami (2017) suggested a cut-off of $26.1 \%$ for the SCD assay which can differentiate infertile and fertile men, while Lopes, Jurisicova, Sun, and Casper (1998) reported a cut-off value of $25.5 \%$ for the TUNEL assay to distinguish between successful and unsuccessful IVF or ICSI outcomes. The SCSA was also studied to establish an association with ART outcomes (Bungum et al., 2004; Richthoff et al., 2002; Virro et al., 2004), while a number of meta-analyses showed no or only poor predictive value for IVF and ICSI outcomes (Cissen et al., 2016; Simon, Zini et al., 2017; Zhang et al., 2015). On the other hand, these studies indicated a medium to good predictive power when the TUNEL, SCD and comet assay were performed.

Van de Kerckhove et al. performed the SCD test with a DFI cutoff of $20 \%$ for couples who had unexplained infertility and underwent IUI, and reported 42.9\% SDF incidence (Van de Kerckhove, De Croo, Gerris, Vanden Abbeel, \& De Sutter, 2016). Controversies still exist in the ability of SDF results to predict IVF and ICSI outcomes, since SDF cannot be used as sole predictor for pregnancy outcomes, as innumerable factors influence ART outcomes (Agarwal, Majzoub, et al., 2016; Esteves, Roque et al., 2017). Nevertheless, as there is a substantial limitation of available evidence, additional in-depth studies are required to determine the effects of SDF on outcomes of medically assisted reproduction.

Some studies have reported that sperm processing by density gradient centrifugation does not affect DNA integrity (Agarwal, Cho et al., 2017b; Bungum et al., 2008; Zini, Nam, Mak, Phang, \& Jarvi, 2000). Hence, the sperm preparation protocol should be carefully selected according to the sperm quality of individual patients. In addition, since SDF testing in neat semen samples gives good results with regard to ART outcomes and a high SDF before density gradient centrifugation predicts impaired SDF after semen processing, SDF testing after density gradient centrifugation does not provide additional predictive power (Agarwal, Cho, Esteves, \& Majzoub, 2017b).

In infertile men with high-grade varicocele and normal semen parameters, or low-grade varicoceles with abnormal semen parameters, a varicocele repair may be considered. Several studies have shown that higher SDF can also be seen in men with varicocele despite having normal conventional semen parameters (Cho et al., 2016; Esteves, Agarwal, Cho et al., 2017). Following varicocelectomy, a significant decrease in SDF as well as an improvement in the total antioxidant capacity (TAC) has been reported (Abdelbaki, Sabry, Al-Adl, \& Sabry, 2017; Telli et al., 2015; Werthman, Wixon, Kasperson, \& Evenson, 2008). Consequently, with respect to varicocele, Agarwal et al. proposed guidelines indicating that the recognition of SDF as clinical parameter may significantly alter the clinical treatment offered by fertility specialists in regard to infertile men with varicoceles and normal semen parameters (Agarwal, Cho, Majzoub et al., 2017).

Generally, based on the findings of SDF studies, clinicians may recommend SDF testing for infertile men. However, since there is a lack of strong evidence in respect of the best clinical indications in terms of the identification of the appropriate patient and 
possible management of the condition, more carefully designed studies need to be conducted. Criteria regarding the patient's lifestyle need to be kept in consideration, as lifestyle changes can reduce SDF in men with impaired or borderline semen parameters (Esteves, Majzoub, \& Agarwal, 2017b). Lifestyle modifications such as changes in dietary patterns have been shown to improve DFI, sperm concentration and serum testosterone levels. Antioxidants can also provide beneficial effects on sperm functions, ART outcomes and live birth rate (Busetto et al., 2018; Greco et al., 2005; Majzoub \& Agarwal, 2018). In light of these results, additional studies with appropriate methods to assess the value of antioxidant therapy in the management of SDF in infertile men are needed (Alahmar, Calogero, Sengupta, \& Dutta, 2020; Izuka, Menuba, Sengupta, Dutta, \& Nwagha, 2020; Majzoub, Agarwal, \& Esteves, 2017).

\section{5 | INDICATIONS OF SPERM DNA INTEGRITY TESTING}

\section{1 | Clinical implications of sperm chromatin integrity testing}

Evaluating implications of sperm chromatin integrity tests can be complex as the term 'chromatin integrity' includes different aspects, namely chromatin condensation and DNA damage, both of which are interrelated. Therefore, it is difficult to correlate 'chromatin integrity' with specific processes of defined mechanisms and it would be better to differentiate clearly between chromatin condensation and DNA damage. The different types of DNA damage need to be acknowledged and approached separately. This might be one reason why there is not only confusion, but also no consensus about its clinical value. In addition, confounding factors, such as the lack of clearly defined clinical conditions where SDF or sperm chromatin condensation testing makes sense and should be recommended, contribute to the complexity and interpretation of these test results.

Majzoub et al. conducted a cross-sectional survey on the current practices of fertility specialists from 49 countries and report that $79.6 \%$ of the specialists commonly order SDF testing, of which the most frequently used assays are the TUNEL assay and SCSA (both $30.6 \%)$. The most common indication for ordering the test was recurrent conventional IVF failure or pregnancy loss after IVF (91.8\%). Other indications were recurrent first-trimester natural pregnancy loss and recurrent pregnancy loss following ICSI (85.7\% for both). High cost (46.9\%), poor validation (36.7\%) and low precision (18.3\%) were the most frequently reported reasons for not using SDF testing (Majzoub, Agarwal, Cho, \& Esteves, 2017).

Nevertheless, abnormal SDF can be a predictor of male fertility potential, leading to miscarriage, compromised embryonic development or childhood defects (Agarwal, Cho, Esteves, \& Majzoub, 2017a; Ashwood-Smith \& Edwards, 1996; Cozzubbo, Neri, Rosenwaks, \& Palermo, 2014; Lewis, 2015; Meseguer et al., 2011). Many studies have shown that the rates of sperm DNA damage in infertile and fertile men are significantly different (Bungum et al., 2004; McKelvey-Martin et al., 1997; Payne et al., 2005; Saleh et al., 2003; Sergerie et al., 2005; Tomlinson et al., 2001). Various environmental and lifestyle factors, including varicocele, male accessory gland infections, advanced paternal age and systemic diseases, have been associated with increased sperm DNA damage (Cho et al., 2016; Esteves et al., 2015; Sengupta, Dutta, Alahmar, \& D'souza, U. J. A., 2020; Tiseo, Esteves, \& Cocuzza, 2016). SDF also positively correlates with oxidative stress in varicocele patients (Agarwal, Hamada, \& Esteves, 2012; Blumer et al., 2012; Chen, Huang William, Chang Luke, \& Wei, 2008) and, as discussed earlier, varicocelectomy proved to be beneficial in reducing SDF and improving fertility parameters (Agarwal, Cho, \& Esteves, 2016; Esteves, Roque, \& Agarwal, 2016; Kadioglu, Aliyev, \& Celtik, 2014; Tiseo et al., 2016; Wang, Zhang, Lin, Zhang, \& Zhang, 2012).

In summary, there is likely enough evidence to recommend SDF testing in patients with the following clinical conditions: varicocele, unexplained infertility, recurrent pregnancy loss, recurrent IUI failure, IVF and ICSI failure, and borderline abnormal (or normal) semen parameters with risk factors such as advanced age, smoking obesity or other environmental exposures (Agarwal et al., 2016b; Agarwal, Cho, Majzoub et al., 2017).

\section{2 | Clinical relevance with ART outcomes}

Effective transmission of genetic information to the offspring requires appropriate sperm chromatin integrity in the form of both normal chromatin condensation and minimal sperm DNA damage. Poor sperm chromatin condensation and poor DNA integrity negatively affect natural fertility as well as ART outcomes (Agarwal et al., 2012; Agarwal, Majzoub, et al., 2016; Esteves, 2016; Esteves et al., 2016; Gosálvez et al., 2014; Kumar, Kumar, Jain, Hassan, \& Dada, 2013; Lewis \& Aitken, 2005). Several methods have been proposed to determine SDF with no consensus on the type of test or the cut-off value. Yet, the evidence shows that high SDF significantly and negatively impacts fertilization and the possibility of a successful pregnancy. SDF is also positively correlated with extended time of impregnation in first-time couples without infertility (Buck Louis et al., 2014). The chance of a natural pregnancy can be determined with moderate sensitivity and specificity by both SCD and TUNEL assays (Buck Louis et al., 2014; Wiweko \& Utami, 2017; Zini, 2011). Increased SDF levels also correspond with decreased IUI success rates (Bungum et al., 2007; Duran et al., 2002). A meta-analysis consisting of 8,068 IVF cycles has shown a significant adverse effect of high SDF on clinical pregnancy following both IVF and ICSI (Bungum et al., 2007). Another meta-analysis of 2,969 couples found a more than twofold probability of miscarriage when semen with a high degree of SDF was used for ICSI (Robinson et al., 2012). Likewise, another meta-analysis of pooled data from 14 studies found a correlation between high SDF and failure rates in ICSI (Zhao, Zhang, Wang, \& Li, 2014). Moreover, SDF was significantly higher in couples with repeated 
pregnancy losses compared to fertile controls (Carlini et al., 2017). These observations suggest that SDF tests have the potential to be used as predictor for natural pregnancy as well as for ART outcomes.

\section{6 | FUTURE DIRECTIONS}

Professional societies will need to undertake initiatives to re-review the clinical practice guidelines for SDF testing in the evaluation of infertile men. This has begun with the Society for Translational Medicine which was the first to recommend SDF testing (Agarwal, Cho, Majzoub et al., 2017c). In the best interest of the patients, it is essential to identify those patients who can benefit most from SDF testing. Therefore, further well-designed studies will hopefully determine the clinical importance of SDF testing for the evaluation of underlying mechanisms of infertility in men and identify those patients who will benefit. In addition, efforts must be made to standardise the most accurate tests and to reduce the cost. Eventually, rational treatment options must be developed. Currently, these include change of lifestyle, varicocelectomy, antioxidants-based therapy and use of ART.

\section{7 | CONCLUSION}

There is strong evidence supporting the inclusion of SDF in the evaluation of the infertile men. The present review article focused on the comparison of tests used for the assessment of sperm chromatin integrity and highlighted the benefits and limitations of each test. Sperm chromatin integrity assessment or SDF tests provides vital information in case of unexplained infertility as well as bear high predictive value in natural and assisted reproduction. Selection of the correct assay among the multiple options for SDF testing relies on several factors such as level of complexity of the protocol, equipment cost, the need for skilled experienced technician and wellequipped andrology laboratory. Proper knowledge of the severity and underlying cause of sperm DNA damage is essential to appropriately offer therapeutic treatments to infertile men. Appropriate treatment will aid success rates of natural conception and ART. The diagnostic and prognostic potential of SDF tests is likely better and more specific than routine semen analysis for the assessment of male fertility status in many cases.

\section{8 | TAKE HOME MESSAGE}

- Sperm chromatin integrity analysis provides useful information on the underlying mechanisms of male infertility and serves as predictor of fertility outcomes in both natural reproduction and ART

- Clinically, high sperm DNA fragmentation (SDF) is a paternal-derived defect causing concurrent ART failures and miscarriages.
- Several assays are available for the evaluation of sperm chromatin integrity and SDF, each having its own advantages and limitations.

- It is essential to compare the features of the SDF tests before selection of a specific test to be performed, in order to obtain the most relevant information

- The evaluation of the actual causes of sperm DNA damage is vital to offering appropriate therapeutic strategies.

- Cut-off values for SDF tests have been suggested but require greater validation and consensus.

- Strong evidence supports the inclusion of sperm DNA fragmentation in the evaluation of infertile men.

\section{ORCID}

Ralf Henkel (iD https://orcid.org/0000-0003-1128-2982

Ashok Agarwal iD https://orcid.org/0000-0003-0585-1026

Sulagna Dutta iD https://orcid.org/0000-0002-7893-5282

\section{REFERENCES}

Abdelbaki, S. A., Sabry, J. H., Al-Adl, A. M., \& Sabry, H. H. (2017). The impact of coexisting sperm DNA fragmentation and seminal oxidative stress on the outcome of varicocelectomy in infertile patients: A prospective controlled study. Arab Journal of Urology, 15(2), 131-139. https://doi.org/10.1016/j.aju.2017.03.002

Agarwal, A., Cho, C.-L., \& Esteves, S. C. (2016). Should we evaluate and treat sperm DNA fragmentation? Current Opinion in Obstetrics and Gynecology, 28(3), 164-171. https://doi.org/10.1097/gco.00000 00000000271

Agarwal, A., Cho, C.-L., Esteves, S. C., \& Majzoub, A. (2017a). Current limitation and future perspective of sperm DNA fragmentation tests. Translational Andrology and Urology, 6(Suppl 4), S549-S552. https:// doi.org/10.21037/tau.2017.05.11

Agarwal, A., Cho, C.-L., Esteves, S. C., \& Majzoub, A. (2017b). Implication of sperm processing during assisted reproduction on sperm DNA integrity. Translational Andrology and Urology, 6, S583-S585.

Agarwal, A., Cho, C.-L., Majzoub, A., \& Esteves, S. C. (2017c). The Society for Translational Medicine: Clinical practice guidelines for sperm DNA fragmentation testing in male infertility. Translational Andrology and Urology, 6, S720-S733.

Agarwal, A., Hamada, A., \& Esteves, S. C. (2012). Insight into oxidative stress in varicocele-associated male infertility: Part 1. Nature Reviews Urology, 9, 678. https://doi.org/10.1038/nrurol.2012.197

Agarwal, A., Majzoub, A., Esteves, S. C., Ko, E., Ramasamy, R., \& Zini, A. (2016). Clinical utility of sperm DNA fragmentation testing: Practice recommendations based on clinical scenarios. Translational Andrology and Urology, 5(6), 935-950. https://doi.org/10.21037/ tau.2016.10.03

Agarwal, A., \& Said, T. M. (2003). Role of sperm chromatin abnormalities and DNA damage in male infertility. Human Reproduction Update, 9(4), 331-345. https://doi.org/10.1093/humupd/dmg027

Agarwal, A., \& Sengupta, P. (2020). Oxidative Stress and its Association with Male Infertility. In Male Infertility (pp. 57-68). Springer.

Agarwal, A., Varghese, A. C., \& Sharma, R. K. (2009). Markers of oxidative stress and sperm chromatin integrity. In O.-K. Park-Sarge, \& T. E. Curry (Eds.), Molecular endocrinology: Methods and protocols (pp. 377-402). Totowa, NJ: Humana Press.

Aitken, R. J. (1995). Free radicals, lipid peroxidation and sperm function. Reproduction, Fertility, and Development, 7, 659-668.

Aitken, R. J. (2006). Sperm function tests and fertility. International Journal of Andrology, 29, 69-75.

Aitken, R. J., De luliis, G. N., Finnie, J. M., Hedges, A., \& McLachlan, R. I. (2010). Analysis of the relationships between oxidative stress, DNA 
damage and sperm vitality in a patient population: Development of diagnostic criteria. Human Reproduction, 25(10), 2415-2426. https:// doi.org/10.1093/humrep/deq214

Aitken, R. J., De luliis, G. N., \& McLachlan, R. I. (2009). Biological and clinical significance of DNA damage in the male germ line. International Journal of Andrology, 32, 46-56.

Alahmar, A. T., Calogero, A. E., Sengupta, P., \& Dutta, S. (2020). Coenzyme Q10 improves sperm parameters, oxidative stress markers and sperm DNA fragmentation in infertile patients with idiopathic oligoasthenozoospermia. The World Journal of Men's Health, 38. https://doi. org/10.5534/wjmh.190145

Amann, R. P. (1989). Can the fertility potential of a seminal sample be predicted accurately? Journal of Andrology, 10, 89-98.

Amann, R. P., \& Hammerstedt, R. H. (1993). In vitro evaluation of sperm quality: An opinion. Journal of Andrology, 14, 397-406.

Anifandis, G., Bounartzi, T., Messini, C. I., Dafopoulos, K., Markandona, R., Sotiriou, S., ... Messinis, I. E. (2015). Sperm DNA fragmentation measured by Halosperm does not impact on embryo quality and ongoing pregnancy rates in IVF/ICSI treatments. Andrologia, 47, 295-302.

Aoki, V. W., Liu, L., \& Carrell, D. T. (2005). Identification and evaluation of a novel sperm protamine abnormality in a population of infertile males. Human Reproduction, 20(5), 1298-1306.

Ashwood-Smith, M., \& Edwards, R. (1996). Genetics and human conception: DNA repair by oocytes. MHR: Basic Science of Reproductive Medicine, 2(1), 46-51.

Balhorn, R. (1982). A model for the structure of chromatin in mammalian sperm. Journal of Cell Biology, 93, 298-305.

Barazani, Y., Agarwal, A., \& Sabanegh, E. S. Jr (2014). Functional sperm testing and the role of proteomics in the evaluation of male infertility. Urology, 84, 255-261.

Barratt, C. L., Mansell, S., Beaton, C., Tardif, S., \& Oxenham, S. K. (2011). Diagnostic tools in male infertility-the question of sperm dysfunction. Asian Journal of Andrology, 13(1), 53.

Baskaran, S., Agarwal, A., Panner Selvam, M. K., Finelli, R., Robert, K. A., lovine, C., ... Henkel, R. (2019). Tracking research trends and hotspots in sperm DNA fragmentation testing for the evaluation of male infertility: A scientometric analysis. Reproductive Biology and Endocrinology, 17, 110.

Benchaib, M., Braun, V., Lornage, J., Hadj, S., Salle, B., Lejeune, H., \& Guérin, J. F. (2003). Sperm DNA fragmentation decreases the pregnancy rate in an assisted reproductive techniqu. Human Reproduction, 18(5), 1023-1028. https://doi.org/10.1093/HUMREP/DEG228

Bianchi, P. G., Manicardi, G. C., Bizzaro, D., Bianchi, U., \& Sakkas, D. (1993). Effect of deoxyribonucleic acid protamination on fluorochrome staining and in situ nick-translation of murine and human mature spermatozoa. Biology of Reproduction, 49, 1083-1088.

Blumer, C. G., Restelli, A. E., Giudice, P. T. D., Soler, T. B., Fraietta, R., Nichi, M., ... Cedenho, A. P. (2012). Effect of varicocele on sperm function and semen oxidative stress. BJU International, 109(2), 259265. https://doi.org/10.1111/j.1464-410X.2011.10240.x

Borges, E. Jr, Zanetti, B. F., Setti, A. S., Braga, D. P. A. F., Provenza, R. R., \& laconelli A. Jr (2019). Sperm DNA fragmentation is correlated with poor embryo development, lower implantation rate, and higher miscarriage rate in reproductive cycles of non-male factor infertility. Fertility and Sterility, 112, 483-490. https://doi.org/10.1016/j.fertn stert.2019.04.029

Buck Louis, G. M., Sundaram, R., Schisterman, E. F., Sweeney, A., Lynch, C. D., Kim, S., ... Chen, Z. (2014). Semen quality and time to pregnancy: The Longitudinal Investigation of Fertility and the Environment Study. Fertility and Sterility, 101(2), 453-462. https:// doi.org/10.1016/j.fertnstert.2013.10.022

Bui, A. D., Sharma, R., Henkel, R., \& Agarwal, A. (2018). Reactive oxygen species impact on sperm DNA and its role in male infertility. Andrologia, 50, e13012.
Bungum, M., Humaidan, P., Axmon, A., Spano, M., Bungum, L., Erenpreiss, J., \& Giwercman, A. (2007). Sperm DNA integrity assessment in prediction of assisted reproduction technology outcome. Human Reproduction, 22(1), 174-179. https://doi.org/10.1093/humrep/ del326

Bungum, M., Humaidan, P., Spano, M., Jepson, K., Bungum, L., \& Giwercman, A. (2004). The predictive value of sperm chromatin structure assay (SCSA) parameters for the outcome of intrauterine insemination, IVF and ICSI. Human Reproduction, 19(6), 1401-1408. https://doi.org/10.1093/humrep/deh280

Bungum, M., Spanò, M., Humaidan, P., Eleuteri, P., Rescia, M., \& Giwercman, A. (2008). Sperm chromatin structure assay parameters measured after density gradient centrifugation are not predictive for the outcome of ART. Human Reproduction, 23(1), 4-10. https://doi. org/10.1093/humrep/dem353

Busetto, G. M., Agarwal, A., Virmani, A., Antonini, G., Ragonesi, G., Del Giudice, F., ... De Berardinis, E. (2018). Effect of metabolic and antioxidant supplementation on sperm parameters in oligo-astheno-teratozoospermia, with and without varicocele: A double-blind placebo-controlled study. Andrologia, 50, e12927. https://doi. org/10.1111/and.12927

Cambi, M., Tamburrino, L., Marchiani, S., Olivito, B., Azzari, C., Forti, G., ... Muratori, M. (2013). Development of a specific method to evaluate 8-hydroxy, 2-deoxyguanosine in sperm nuclei: Relationship with semen quality in a cohort of 94 subjects. Reproduction, 145, 227-235.

Carlini, T., Paoli, D., Pelloni, M., Faja, F., Dal Lago, A., Lombardo, F., ... Gandini, L. (2017). Sperm DNA fragmentation in Italian couples with recurrent pregnancy loss. Reproductive BioMedicine Online, 34(1), 58-65. https://doi.org/10.1016/j.rbmo.2016.09.014

Carrell, D. T., Liu, L., Peterson, C., Jones, K., Hatasaka, H., Erickson, L., \& Campbell, B. (2003). Sperm DNA fragmentation is increased in couples with unexplained recurrent pregnancy loss. Archives of Andrology, 49(1), 49-55.

Casanovas, A., Ribas-Maynou, J., Lara-Cerrillo, S., Jimenez-Macedo, A. R., Hortal, O., Benet, J., ... Garcia-Peiro, A. (2019). Double-stranded sperm DNA damage is a cause of delay in embryo development and can impair implantation rates. Fertility and Sterility, 111, 699-707.

Chen, J. L., \& Longo, F. J. (1996). Expression and localization of DNA topoisomerase II durng rat spermatogenesis. Molecular Reproduction and Development, 45, 61-71.

Chen, S.-S., Huang William, J., Chang Luke, S., \& Wei, Y.-H. (2008). Attenuation of oxidative stress after varicocelectomy in subfertile patients with varicocele. Journal of Urology, 179(2), 639-642. https:// doi.org/10.1016/j.juro.2007.09.039

Cho, C. L., \& Agarwal, A. (2017). Role of sperm DNA fragmentation in male factor infertility: A systematic review. Arab Journal of Urology, 16, 21-34.

Cho, C.-L., Esteves, S., \& Agarwal, A. (2016). Novel insights into the pathophysiology of varicocele and its association with reactive oxygen species and sperm DNA fragmentation. Asian Journal of Andrology, 18(2), 186-193. https://doi.org/10.4103/1008-682x.170441

Cissen, M., Wely, M. V., Scholten, I., Mansell, S., Bruin, J. P., Mol, B. W., ... Hamer, G. (2016). Measuring sperm DNA fragmentation and clinical outcomes of medically assisted reproduction: A systematic review and meta-analysis. PLoS One, 11, e0165125.

Collins, J. A., Barnhart, K. T., \& Schlegel, P. N. (2008). Do sperm DNA integrity tests predict pregnancy with in vitro fertilization? Fertility and Sterility, 89(4), 823-831. https://doi.org/10.1016/j.fertn stert.2007.04.055

Cortés-Gutiérrez, E. I., Fernández, J. L., Dávila-Rodríguez, M. I., LópezFernández, C., \& Gosálvez, J. (2017). Two-Tailed Comet Assay (2T-Comet): Simultaneous detection of DNA single and double strand breaks. In C. Pellicciari, \& M. Biggiogera (Eds.), Histochemistry of single molecules: Methods and protocols (pp. 285-293). New York, NY: Springer New York. 
Cozzubbo, T., Neri, Q. V., Rosenwaks, Z., \& Palermo, G. D. (2014). To what extent can oocytes repair sperm DNA fragmentation? Fertility and Sterility, 102(3), e61. https://doi.org/10.1016/j.fertn stert.2014.07.208

Cui, Z. L., Zheng, D. Z., Liu, Y. H., Chen, L. Y., Lin, D. H., \& Lan, F.-H. (2015). Diagnostic accuracies of the TUNEL, SCD, and Comet based sperm DNA fragmentation assays for male infertility: A Meta-analysis study. Clinical Laboratory, 61, 525-535.

Dadoune, J. P., Mayaux, M. J., \& Guihard-Moscato, M. L. (1988). Correlation between defects in chromatin condensation of human spermatozoa stained by aniline blue and semen characteristics. Andrologia, 20, 211-217.

De luliis, G. N., Thomson, L. K., Mitchell, L. A., Finnie, J. M., Koppers, A. J., Hedges, A., ... Aitken, R. J. (2009). DNA damage in human spermatozoa is highly correlated with the efficiency of chromatin remodeling and the formation of 8-Hydroxy-2'-Deoxyguanosine, a marker of oxidative stress1. Biology of Reproduction, 81(3), 517-524. https://doi. org/10.1095/biolreprod.109.076836

Deng, C., Li, T., Xie, Y., Guo, Y., Yang, Q. Y., Liang, X., ... Liu, G. H. (2019). Sperm DNA fragmentation index influences assisted reproductive technology outcome: A systematic review and meta-analysis combined with a retrospective cohort study. Andrologia, 51, e13263.

Durairajanayagam, D. (2018). Lifestyle causes of male infertility. Arab Journal of Urology, 16, 10-20.

Duran, E. H., Morshedi, M., Taylor, S., \& Oehninger, S. (2002). Sperm DNA quality predicts intrauterine insemination outcome: A prospective cohort stud. Human Reproduction, 17(12), 3122-3128.

Duty, S. M., Singh, N. P., Ryan, L., Chen, Z., Lewis, C., Huang, T., \& Hauser, R. (2002). Andrology. Reliability of the comet assay in cryopreserved human. Human Reproduction, 17(5), 1274-1280.

Enciso, M., Sarasa, J., Agarwal, A., Fernández, J. L., \& Gosálvez, J. (2009). A two-tailed Comet assay for assessing DNA damage in spermatozoa. Reproductive BioMedicine Online, 18(5), 609-616. https://doi. org/10.1016/S1472-6483(10)60003-X

Erenpreisa, J., Erenpreiss, J., Freivalds, T., Slaidina, M., Krampe, R., Butikova, J., ... Pjanova, D. (2003). Toluidine blue test for sperm DNA integrity and elaboration of image cytometry algorithm. Cytometry Part A, 52A(1), 19-27. https://doi.org/10.1002/cyto.a.10015

Erenpreiss, J., Bars, J., Lipatnikova, V., Erenpreisa, J., \& Zalkalns, J. (2001). Comparative study of cytochemical tests for sperm chromatin integrity. Journal of Andrology, 22(1), 45-53. https://doi. org/10.1002/j.1939-4640.2001.tb02152.x

Erenpreiss, J., Jepson, K., Giwercman, A., Tsarev, I., Erenpreisa, J., \& Spano, M. (2004). Toluidine blue cytometry test for sperm DNA conformation: Comparison with the flow cytometric sperm chromatin structure and TUNEL assays. Human Reproduction, 19(10), 22772282. https://doi.org/10.1093/humrep/deh417

Esterbauer, H. (1993). Cytotoxicity and genotoxicity of lipid-oxidation products. American Journal of Clinical Nutrition, 57(5 Suppl), 779S-786S

Esterhuizen, A., Franken, D., Lourens, J., Prinsloo, E., \& Van Rooyen, L. (2000). Sperm chromatin packaging as an indicator of in-vitro fertilization rates. Human Reproduction, 15(3), 657-661.

Esteves, S. C. (2016). Novel concepts in male factor infertility: Clinical and laboratory perspectives. Journal of Assisted Reproduction and Genetics, 33(10), 1319-1335. https://doi.org/10.1007/s1081 5-016-0763-8

Esteves, S. C., \& Agarwal, A. (2011). Novel concepts in male infertility. International Brazilian Journal of Urology, 37, 5-15.

Esteves, S. C., Agarwal, A., Cho, C.-L., \& Majzoub, A. (2017). A Strengths-Weaknesses-Opportunities-Threats (SWOT) analysis on the clinical utility of sperm DNA fragmentation testing in specific male infertility scenarios. Translational Andrology and Urology, 6, S734-S760.
Esteves, S. C., Agarwal, A., \& Majzoub, A. (2017). The complex nature of the sperm DNA damage process. Translational Andrology and Urology, 6, S557-S559.

Esteves, S. C., Gosálvez, J., López-Fernández, C., Núñez-Calonge, R., Caballero, P., Agarwal, A., \& Fernández, J. L. (2015). Diagnostic accuracy of sperm DNA degradation index (DDSi) as a potential noninvasive biomarker to identify men with varicocele-associated infertility. International Urology and Nephrology, 47(9), 1471-1477. https://doi. org/10.1007/s11255-015-1053-6

Esteves, S. C., Majzoub, A., \& Agarwal, A. (2017a). Further evidence supports the clinical utility of sperm DNA fragmentation testing in male infertility workup and assisted reproductive technology. Translational Andrology and Urology, 6, S428-S436.

Esteves, S. C., Majzoub, A., \& Agarwal, A. (2017b). The importance of quality control and quality assurance in SDF testing. Translational Andrology and Urology, 6, S604-S606.

Esteves, S., Roque, M., \& Agarwal, A. (2016). Outcome of assisted reproductive technology in men with treated and untreated varicocele: Systematic review and meta-analysis. Asian Journal of Andrology, 18(2), 254-258. https://doi.org/10.4103/1008-682x.163269

Esteves, S. C., Roque, M., Bradley, C. K., \& Garrido, N. (2017). Reproductive outcomes of testicular versus ejaculated sperm for intracytoplasmic sperm injection among men with high levels of DNA fragmentation in semen: Systematic review and meta-analysis. Fertility and Sterility, 108, 456-467.

Esteves, S. C., Sharma, R. K., Gosálvez, J., \& Agarwal, A. (2014). A translational medicine appraisal of specialized andrology testing in unexplained male infertility. International Urology and Nephrology, 46(6), 1037-1052. https://doi.org/10.1007/s11255-014-0715-0

Evenson, D. P. (2016). The Sperm Chromatin Structure Assay (SCSA(®)) and other sperm DNA fragmentation tests for evaluation of sperm nuclear DNA integrity as related to fertility. Animal Reproduction Science, 169, 56-75.

Evenson, D. P., Darzynkiewicz, Z., \& Melamed, M. R. (1980). Comparison of human and mouse sperm chromatin structure by flow cytometry. Chromosoma, 78, 225-238.

Evenson, D. P., Jost, L. K., Marshall, D., Zinaman, M. J., Clegg, E., Purvis, K., ... Claussen, O. P. (1999). Utility of the sperm chromatin structure assay as a diagnostic and prognostic tool in the human fertility clini. Human Reproduction, 14(4), 1039-1049.

Evenson, D., \& Wixon, R. (2006). Meta-analysis of sperm DNA fragmentation using the sperm chromatin structure assay. Reproductive BioMedicine Online, 12(4), 466-472. https://doi.org/10.1016/S1472 $-6483(10) 62000-7$

Feijó, C. M., \& Esteves, S. C. (2014). Diagnostic accuracy of sperm chromatin dispersion test to evaluate sperm deoxyribonucleic acid damage in men with unexplained infertility. Fertility and Sterility, 101(1), 58-63. e53.

Fernández, J. L., Muriel, L., Goyanes, V., Segrelles, E., Gosálvez, J., Enciso, M., ... De Jonge, C. (2005). Halosperm ${ }^{\circledR}$ is an easy, available, and cost-effective alternative for determining sperm DNA fragmentation. Fertility and Sterility, 84(4), 860. https://doi.org/10.1016/j.fertn stert.2005.05.013

Fernández, J. L., Muriel, L., Rivero, M. T., Goyanes, V., Vazquez, R., \& Alvarez, J. G. (2003). The sperm chromatin dispersion test: A simple method for the determination of sperm DNA fragmentation. Journal of Andrology, 24(1), 59-66. https://doi.org/10.1002/j.1939-4640.2003. tb02641.x

Foresta, C., Zorzi, M., Rossato, M., \& Varotto, A. (1992). Sperm nuclear instability and staining with aniline blue: Abnormal persistance of histones in spermatozoa in infertile men. International Journal of Andrology, 15(4), 330-337.

Franco, J. Jr, Mauri, A., Petersen, C., Massaro, F., Silva, L., Felipe, V., ... Oliveira, J. (2012). Large nuclear vacuoles are indicative of abnormal 
chromatin packaging in human spermatozoa. International Journal of Andrology, 35(1), 46-51.

Franken, D. R., \& Henkel, R. (2010). Sperm functional assays. In S. Tandulwadkar, \& B. Mittal (Eds.), Optimizing IUI results - A guide to gynecologists (pp.155-167). New Delhi, India: Jaypee Brothers Medical Publishers (P) Ltd.

Franken, D. R., Oehninger, S., Burkman, L. J., Coddington, C. C., Kruger, T. F., Rosenwaks, Z., ... Hodgen, G. D. (1989). The Hemizona Assay (HZA): A predictor of human sperm fertilizing potential in in vitro fertilization (IVF) treatment. Journal of in Vitro Fertilization and Embryo Transfer, 6, 44-50.

Fuentes-Mascorro, G., Serrano, H., \& Rosado, A. (2000). Sperm chromatin. Archives of Andrology, 45(3), 215-225.

Giwercman, A., Lindstedt, L., Larsson, M., Bungum, M., Spano, M., Levine, R. J., \& Rylander, L. (2010). Sperm chromatin structure assay as an independent predictor of fertility in vivo: A case-control study. International Journal of Andrology, 33(1), e221-e227.

Gosálvez, J., Rodríguez-Predreira, M., Mosquera, A., López-Fernández, C., Esteves, S., Agarwal, A., \& Fernandez, J. (2014). Characterisation of a subpopulation of sperm with massive nuclear damage, as recognised with the sperm chromatin dispersion test. Andrologia, 46(6), 602-609.

Greco, E., Romano, S., lacobelli, M., Ferrero, S., Baroni, E., Minasi, M. G. ... Tesarik, J. (2005). ICSI in cases of sperm DNA damage: Beneficial effect of oral antioxidant treatment. Human Reproduction, 20(9), 2590-2594. https://doi.org/10.1093/humrep/dei091

Guzick, D. S., Overstreet, J. W., Factor-Litvak, P., Brazil, C. K., Nakajima, S. T., Coutifaris, C., ... Hill, J. A. (2001). Sperm morphology, motility, and concentration in fertile and infertile men. New England Journal of Medicine, 345(19), 1388-1393.

Haidl, G., \& Schill, W. B. (1994). Assessment of sperm chromatin condensation: An important test for prediction of IVF outcome. Archives of Andrology, 32, 263-266.

Hammadeh, M. E., Al-Hasani, S., Stieber, M., Rosenbaum, P., Kupker, D. Diedrich, K., \& Schmidt, W. (1996). The effect of chromatin condensation (aniline blue staining) and morphology (strict criteria) of human spermatozoa on fertilization, cleavage and pregnancy rates in an intracytoplasmic sperm injection programme. Human Reproduction, 11, 2468-2471.

Hammadeh, M. E., Stieber, M., Haidl, G., \& Schmidt, W. (1998). Association between sperm cell chromatin condensation, morphology based on strict criteria, and fertilization, cleavage and pregnancy rates in an IVF program. Andrologia, 30, 29-35.

Hammadeh, M., Zeginiadov, T., Rosenbaum, P., Georg, T., Schmidt, W., \& Strehler, E. (2001). Predictive value of sperm chromatin condensation (aniline blue staining) in the assessment of male fertility. Archives of Andrology, 46(2), 99-104.

Hellman, B., Vaghef, H., \& Boström, B. (1995). The concepts of tail moment and tail inertia in the single cell gel electrophoresis assay. Mutation Research/DNA Repair, 336(2), 123-131.

Henkel, R. (2007). DNA-based sperm assessment. In T. F. Kruger, Z. van der Spuy, \& R. D. Kempers (Eds.), Advances in fertility studies and reproductive medicine (pp. 284-292). Lansdown, South Africa: Juta.

Henkel, R. (2018). Environmental contamination and testicular function. In S. C. Sikka, \& W. J. G. Hellstrom (Eds.), Handbook of bioenvironmental toxicology: Men's reproductive \& sexual health (pp. 191-208). London, UK: Elsevier Inc.

Henkel, R. R., \& Franken, D. R. (2011). Sperm DNA fragmentation: Origin and impact on human reproduction. Journal of Reproductive and Stem Cell Biotechnology, 2(2), 88-108.

Henkel, R., Hajimohammad, M., Stalf, T., Hoogendijk, C., Mehnert, C., Menkveld, R., ... Kruger, T. F. (2004). Influence of deoxyribonucleic acid damage on fertilization and pregnancy. Fertility and Sterility, 81, 965-972.
Henkel, R., Maaß, G., Bödeker, R.-H., Scheibelhut, C., Stalf, T., Mehnert, C., ... Schill, W.-B. (2005). Sperm function and assisted reproduction technology. Reproductive Medicine and Biology, 4, 7-30.

Hirano, T. (2002). The ABCs of SMC proteins: Two-armed ATPases for chromosome condensation, cohesion, and repair. Genes \& Development, 16, 399-414.

Hoshi, K., Katayose, H., Yanagida, K., Kimura, Y., \& Sato, A. (1996). The relationship between acridine orange fluorescence of sperm nuclei and the fertilizing ability of human sperm. Fertility and Sterility, 66(4), 634-639.

Hwang, K., Lipshultz, L. I., \& Lamb, D. J. (2011). Use of diagnostic testing to detect infertility. Current Urology Reports, 12(1), 68-76.

Ishikawa, T., Fujioka, H., Ishimura, T., Takenaka, A., \& Fujisawa, M. (2007). Increased testicular 8-hydroxy-2'-deoxyguanosine in patients with varicocele. BJU International, 100(4), 863-866. https://doi. org/10.1111/j.1464-410X.2007.07008.x

Izuka, E., Menuba, I., Sengupta, P., Dutta, S., \& Nwagha, U. (2020). Antioxidants, anti-inflammatory drugs and antibiotics in the treatment of reproductive tract infections and their association with male infertility. Chemical Biology Letters, 7(2), 156-165.

Javed, A., Talkad, M. S., \& Ramaiah, M. K. (2019). Evaluation of sperm DNA fragmentation using multiple methods: A comparison of their predictive power for male infertility. Clinical and Experimental Reproductive Medicine, 46, 14-21.

Johnson, S. L., Dunleavy, J., Gemmell, N. J., \& Nakagawa, S. (2015). Consistent age-dependent declines in human semen quality: A systematic review and meta-analysis. Ageing Research Reviews, 19, 22-33.

Kadioglu, T. C., Aliyev, E., \& Celtik, M. (2014). Microscopic varicocelectomy significantly decreases the sperm DNA fragmentation index in patients with infertility. BioMed Research International, 2014, 1-4.

Kamiyama, M. (1968). Mechanism of action of chromomycin A3. 3. On the binding of chromomycin A3 with DNA and physiochemical properties of the complex. Journal of Biochemistry, 63, 566-572.

Kasai, H. (1997). Analysis of a form of oxidative DNA damage, 8-hydroxy-2'-deoxyguanosine, as a marker of cellular oxidative stress during carcinogenesis. Mutation Research, 387, 147-163.

Katayose, H., Yanagida, K., Hashimoto, S., Yamada, H., \& Sato, A. (2003). Use of diamide-acridine orange fluorescence staining to detect aberrant protamination of human-ejaculated sperm nuclei. Fertility and Sterility, 79, 670-676. https://doi.org/10.1016/S0015 -0282(02)04815-X

Kazerooni, T., Asadi, N., Jadid, L., Kazerooni, M., Ghanadi, A., Ghaffarpasand, F., ... Zolghadr, J. (2009). Evaluation of sperm's chromatin quality with acridine orange test, chromomycin $\mathrm{A} 3$ and aniline blue staining in couples with unexplained recurrent abortion. Journal of Assisted Reproduction and Genetics, 26, 591-596.

Kim, H.-S., Kang, M. J., Kim, S. A., Oh, S. K., Kim, H., Ku, S.-Y., ... Choi, Y. M. (2013). The utility of sperm DNA damage assay using toluidine blue and aniline blue staining in routine semen analysis. Clinical and Experimental Reproductive Medicine, 40(1), 23-28.

Kızılay, F., \& Altay, B. (2017). Sperm function tests in clinical practice. Turkish Journal of Urology, 43, 393-400.

Kodama, H., Yamaguchi, R., Fukuda, J., Kasai, H., \& Tanaka, T. (1997). Increased oxidative deoxyribonucleic acid damage in the spermatozoa of infertile male patients. Fertility and Sterility, 68(3), 519-524. https://doi.org/10.1016/S0015-0282(97)00236-7

Krawetz, S. A., \& Dixon, G. H. (1988). Sequence similarities of the protamine genes: Implications for regulation and evolution. Journal of Molecular Evolution, 27, 291-297.

Kumar, M., Kumar, K., Jain, S., Hassan, T., \& Dada, R. (2013). Novel insights into the genetic and epigenetic paternal contribution to the human embryo. Clinics (Sao Paulo, Brazil), 68(Suppl 1), 5-14. https:// doi.org/10.6061/clinics/2013(Sup01)02 
Lee, J., Richburg, J. H., Younkin, S. C., \& Boekelheide, K. (1997). The Fas system is a key regulator of germ cell apoptosis in the testis. Endocrinology, 138, 2081-2088.

Lefievre, L., Bedu-Addo, K., Conner, S. J., Machado-Oliveira, G. S., Chen, Y., Kirkman-Brown, J. C., ... Barratt, C. L. (2007). Counting sperm does not add up any more: Time for a new equation? Reproduction, 133, 675-684.

Leisegang, K., \& Dutta, S. (2020). Lifestyle management approaches to male infertility. In B. Rizk, A. Agarwal, E. S. Sabanegh Jr (Eds.), Male Infertility in Reproductive Medicine. Diagnosis and Management, 1st Edn; Boca Raton, USA: CRC Press.

Lewis, S. E. M. (2013). The place of sperm DNA fragmentation testing in current day fertility management. Middle East Fertility Society Journal, 18, 78-82.

Lewis, S. E. M. (2015). Should sperm DNA fragmentation testing be included in the male infertility work-up? Reproductive BioMedicine Online, 31(2), 134-137. https://doi.org/10.1016/j. rbmo.2015.05.006

Lewis, S. E. M., \& Agbaje, I. M. (2008). Using the alkaline comet assay in prognostic tests for male infertility and assisted reproductive technology outcomes. Mutagenesis, 23(3), 163-170. https://doi. org/10.1093/mutage/gem052

Lewis, S. E. M., \& Aitken, R. J. (2005). DNA damage to spermatozoa has impacts on fertilization and pregnancy. Cell and Tissue Research, 322(1), 33-41. https://doi.org/10.1007/s00441-005-1097-5

Lewis, S. E. M., \& Simon, L. (2010). Clinical implications of sperm DNA damage. Human Fertility, 13(4), 201-207. https://doi.org/10.3109/14647 273.2010.528823

Li, Z., Wang, L., Cai, J., \& Huang, H. (2006). Correlation of sperm DNA damage with IVF and ICSI outcomes: A systematic review and meta-analysis. Journal of Assisted Reproduction and Genetics, 23(9), 367376. https://doi.org/10.1007/s10815-006-9066-9

Loft, S., \& Poulsen, H. E. (1996). Cancer risk and oxidative DNA damage in man. Journal of Molecular Medicine, 74, 297-312.

Lolis, D., Georgiou, I., Syrrou, M., Zikopoulos, K., Konstantelli, M., \& Messinis, I. (1996). Chromomycin A3-staining as an indicator of protamine deficiency and fertilization. International Journal of Andrology, 19, 23-27.

Lopes, S., Jurisicova, A., Sun, J.-G., \& Casper, R. F. (1998). Reactive oxygen species: Potential cause for DNA fragmentation in human spermatozoa. Human Reproduction (Oxford, England), 13(4), 896-900.

Luczaj, W., \& Skrzydlewska, E. (2003). DNA damage caused by lipid peroxidation products. Cellular \& Molecular Biology Letters, 8, 391-413.

Majzoub, A., \& Agarwal, A. (2018). Systematic review of antioxidant types and doses in male infertility: Benefits on semen parameters, advanced sperm function, assisted reproduction and live-birth rate. Arab Journal of Urology, 16(1), 113-124. https://doi.org/10.1016/j. aju.2017.11.013

Majzoub, A., Agarwal, A., Cho, C. L., \& Esteves, S. C. (2017). Sperm DNA fragmentation testing: A cross sectional survey on current practices of fertility specialists. Translational Andrology and Urology, 6(Suppl 4), S710-S719.

Majzoub, A., Agarwal, A., \& Esteves, S. C. (2017). Antioxidants for elevated sperm DNA fragmentation: A mini review. Translational Andrology and Urology, 6, S649-S653.

Majzoub, A., Esteves, S. C., Gosálvez, J., \& Agarwal, A. (2016). Specialized sperm function tests in varicocele and the future of andrology laboratory. Asian Journal of Andrology, 18(2), 205.

Manicardi, G. C., Bianchi, P., Pantano, S., Azzoni, P., Bizzaro, D., Bianchi, U., \& Sakkas, D. (1995). Presence of endogenous nicks in DNA of ejaculated human spermatozoa and its relationship to chromomycin A3 accessibility. Biology of Reproduction, 52(4), 864-867.

Manochantr, S., Chiamchanya, C., \& Sobhon, P. (2012). Relationship between chromatin condensation, DNA integrity and quality of ejaculated spermatozoa from infertile men. Andrologia, 44(3), 187-199.
Mao, C., \& Grimes, D. A. (1988). The sperm penetration assay: Can it discriminate between fertile and infertile men? American Journal of Obstetrics and Gynecology, 159, 279-286.

Marchesi, D. E., Biederman, H., Ferrara, S., Hershlag, A., \& Feng, H. L. (2010). The effect of semen processing on sperm DNA integrity: Comparison of two techniques using the novel Toluidine Blue Assay. European Journal of Obstetrics \& Gynecology and Reproductive Biology, 151(2), 176-180.

Marcon, L., \& Boissonneault, G. (2004). Transient DNA strand breaks during mouse and human spermiogenesis: New insights in stage specificity and link to chromatin remodeling. Biology of Reproduction, 70(4), 910-918.

McKelvey-Martin, V., Melia, N., Walsh, I., Johnston, S., Hughes, C., Lewis, S., \& Thompson, W. (1997). Two potential clinical applications of the alkaline single-cell gel electrophoresis assay:(1) human bladder washings and transitional cell carcinoma of the bladder; and (2) human sperm and male infertility. Mutation Research/Fundamental and Molecular Mechanisms of Mutagenesis, 375(2), 93-104.

McPherson, S. M., \& Longo, F. J. (1992). Localization of DNase I-hypersensitive regions during rat spermatogenesis: Stagedependent patterns and unique sensitivity of elongating spermatids. Molecular Reproduction and Development, 31, 268-279.

McPherson, S. M., \& Longo, F. J. (1993). Nicking of rat spermatid and spermatozoa DNA: Possible involvement of DNA topoisomerase II. Developmental Biology, 158, 122-130.

Meseguer, M., Santiso, R., Garrido, N., García-Herrero, S., Remohí, J., \& Fernandez, J. L. (2011). Effect of sperm DNA fragmentation on pregnancy outcome depends on oocyte quality. Fertility and Sterility, 95(1), 124-128. https://doi.org/10.1016/j.fertnstert.2010.05.055

Meseguer, M., Santiso, R., Garrido, N., Gil-Salom, M., Remohí, J., \& Fernandez, J. L. (2009). Sperm DNA fragmentation levels in testicular sperm samples from azoospermic males as assessed by the sperm chromatin dispersion (SCD) test. Fertility and Sterility, 92(5), 16381645. https://doi.org/10.1016/j.fertnstert.2008.08.106

Miciński, P., Pawlicki, K., Wielgus, E., Bochenek, M., \& Tworkowska, I. (2009). The sperm chromatin structure assay (SCSA) as prognostic factor in IVF/ICSI program. Reproductive Biology, 9(1), 65-70. https:// doi.org/10.1016/S1642-431X(12)60095-3

Mitchell, L. A., De luliis, G. N., \& Aitken, R. J. (2011). The TUNEL assay consistently underestimates DNA damage in human spermatozoa and is influenced by DNA compaction and cell vitality: Development of an improved methodology. International Journal of Andrology, 34(1), 2-13. https://doi.org/10.1111/j.1365-2605.2009.01042.x

Morris, I. D., Ilott, S., Dixon, L., \& Brison, D. R. (2002). Andrology. The spectrum of DNA damage in human sperm assessed by single cell gel electrophoresis (Comet assay) and its relationship to fertilization and embryo developmen. Human Reproduction, 17(4), 990-998.

Muratori, M., Tamburrino, L., Tocci, V., Costantino, A., Marchiani, S., Giachini, C., ... Baldi, E. (2010). Small variations in crucial steps of TUNEL assay coupled to flow cytometry greatly affect measures of sperm DNA fragmentation. Journal of Andrology, 31(4), 336-345. https://doi.org/10.2164/jandrol.109.008508

Muriel, L., Garrido, N., Fernández, J. L., Remohí, J., Pellicer, A., de los Santos, M. J., \& Meseguer, M. (2006). Value of the sperm deoxyribonucleic acid fragmentation level, as measured by the sperm chromatin dispersion test, in the outcome of in vitro fertilization and intracytoplasmic sperm injection. Fertility and Sterility, 85(2), 371-383. https://doi.org/10.1016/j.fertnstert.2005.07.1327

Muriel, L., Meseguer, M., Fernández, J. L., Alvarez, J., Remohí, J., Pellicer, A., \& Garrido, N. (2006). Value of the sperm chromatin dispersion test in predicting pregnancy outcome in intrauterine insemination: A blind prospective study*. Human Reproduction, 21(3), 738-744. https://doi.org/10.1093/humrep/dei403

Oehninger, S., Acosta, A. A., Veeck, L. A., Brzyski, R., Kruger, T. F., \& Muasher, S. J. (1991). Recurrent failure of in vitro fertilization: Role of 
the hemizona assay in the sequential diagnosis of specific sperm-oocyte defects. American Journal of Obstetrics and Gynecology, 164, 1210-1215.

Oehninger, S., Franken, D. R., Sayed, E., Barroso, G., \& Kolm, P. (2000). Sperm function assays and their predictive value for fertilization outcome in IVF therapy: A meta-analysis. Human Reproduction Update, 6, 160-168.

Oehninger, S., \& Ombelet, W. (2019). Limits of current male fertility testing. Fertility and Sterility, 111, 835-841.

Opuwari, C. S., Henkel, R. R., \& Agarwal, A. (2019). Sperm DNA Fragmentation Index. In M. Arora, \& N. Mukhopadhaya (Eds.), Recurrent pregnancy loss (3rd ed., pp. 45-53). New Delhi, India: Jaypee Brothers Publishers.

Panner Selvam, M. K., \& Agarwal, A. (2018). A systematic review on sperm DNA fragmentation in male factor infertility: Laboratory assessment. Arab Journal of Urology, 16, 65-76.

Patel, A. S., Leong, J. Y., \& Ramasamy, R. (2018). Prediction of male infertility by the World Health Organization laboratory manual for assessment of semen analysis: A systematic review. Arab Journal of Urology, 16(1), 96-102.

Payne, J. F., Raburn, D. J., Couchman, G. M., Price, T. M., Jamison, M. G., \& Walmer, D. K. (2005). Redefining the relationship between sperm deoxyribonucleic acid fragmentation as measured by the sperm chromatin structure assay and outcomes of assisted reproductive techniques. Fertility and Sterility, 84(2), 356-364. https://doi. org/10.1016/j.fertnstert.2005.02.032

Poccia, D. (1986). Remodeling of nucleoproteins during gametogenesis, fertilization, and early development. In Z. P. Nagy, A. C. Varghese, A. Agarwal (Eds.), International review of cytology (Vol. 105, pp. 1-65). Burlington: Elsevier.

Practice Committee of the American Society for Reproductive Medicine (2013). The clinical utility of sperm DNA integrity testing: A guideline. Fertility and Sterility, 99, 673-677.

Practice Committee of the American Society for Reproductive Medicine (2015). Diagnostic evaluation of the infertile male: A committee opinion. Fertility and Sterility, 103, e18-e25.

Rehman, I., Ahmad, G., \& Alshahrani, S. (2018). Lifestyle, environment, and male reproductive health: A lesson to learn. In S. C. Sikka, \& W. J. G. Hellstrom (Eds.), Bioenvironmental issues affecting men's reproductive and sexual health (pp. 157-171). London, San Diego, Cambridge, Oxford: Academic Press.

Ribas-Maynou, J., \& Benet, J. (2019). Single and double strand sperm DNA damage: Different reproductive effects on male fertility. Genes (Basel), 10(2), E105. 10.3390/genes10020105

Ribeiro, S., Sharma, R., Gupta, S., Cakar, Z., De Geyter, C., \& Agarwal, A. (2017). Inter- and intra-laboratory standardization of TUNEL assay for assessment of sperm DNA fragmentation. Andrology, 5(3), 477485. https://doi.org/10.1111/andr.12334

Richthoff, J., Spano, M., Giwercman, Y. L., Frohm, B., Jepson, K., Malm, J., ... Giwercman, A. (2002). The impact of testicular and accessory sex gland function on sperm chromatin integrity as assessed by the sperm chromatin structure assay (SCSA). Human Reproduction, 17, 3162-3169.

Robinson, L., Gallos, I. D., Conner, S. J., Rajkhowa, M., Miller, D., Lewis, S., ... Coomarasamy, A. (2012). The effect of sperm DNA fragmentation on miscarriage rates: A systematic review and meta-analysis. Human Reproduction, 27(10), 2908-2917. https://doi.org/10.1093/humrep/ $\operatorname{des} 261$

Roque, M., \& Esteves, S. C. (2018). Effect of varicocele repair on sperm DNA fragmentation: A review. International Urology and Nephrology, 50, 583-603.

Sakkas, D., \& Alvarez, J. G. (2010). Sperm DNA fragmentation: Mechanisms of origin, impact on reproductive outcome, and analysis. Fertility and Sterility, 93(4), 1027-1036.
Sakkas, D., Urner, F., Bizzaro, D., Manicardi, G., Bianchi, P., Shoukir, Y., \& Campana, A. (1998). Sperm nuclear DNA damage and altered chromatin structure: Effect on fertilization and embryo development. Human Reproduction, 13(suppl_4), 11-19.

Saleh, R. A., Agarwal, A., Nada, E. A., El-Tonsy, M. H., Sharma, R. K., Meyer, A., ... Thomas, A. J. (2003). Negative effects of increased sperm DNA damage in relation to seminal oxidative stress in men with idiopathic and male factor infertility. Fertility and Sterility, 79, 1597-1605. https://doi.org/10.1016/S0015-0282(03)00337-6

Santiso, R., Tamayo, M., Gosálvez, J., Meseguer, M., Garrido, N., \& Fernández, J. L. (2010). Simultaneous determination in situ of DNA fragmentation and 8-oxoguanine in human sperm. Fertility and Sterility, 93(1), 314-318. https://doi.org/10.1016/j.fertn stert.2009.07.969

Seli, E., Gardner, D. K., Schoolcraft, W. B., Moffatt, O., \& Sakkas, D. (2004). Extent of nuclear DNA damage in ejaculated spermatozoa impacts on blastocyst development after in vitro fertilization. Fertility and Sterility, 82(2), 378-383.

Sengupta, P., Dutta, S., Alahmar, A. T., \& D'souza, U. J. A. (2020). Reproductive tract infection, inflammation and male infertility. Chemical Biology Letters, 7(2), 75-84.

Sergerie, M., Laforest, G., Bujan, L., Bissonnette, F., \& Bleau, G. (2005). Sperm DNA fragmentation: Threshold value in male fertility. Human Reproduction, 20(12), 3446-3451. https://doi.org/10.1093/humrep/ dei231

Shaha, C., Tripathi, R., \& Mishra, D. P. (2010). Male germ cell apoptosis: Regulation and biology. Philosophical Transactions of the Royal Society B: Biological Sciences, 365(1546), 1501-1515.

Shamsi, M. B., Imam, S. N., \& Dada, R. (2011). Sperm DNA integrity assays: Diagnostic and prognostic challenges and implications in management of infertility. Journal of Assisted Reproduction and Genetics, 28(11), 1073-1085. https://doi.org/10.1007/s10815-011-9631-8

Shamsi, M., Venkatesh, S., Tanwar, M., Singh, G., Mukherjee, S., Malhotra, N., ... Dada, R. (2010). Comet assay: A prognostic tool for DNA integrity assessment in infertile men opting for assisted reproduction. Indian Journal of Medical Research, 131(5), 675-681.

Sharma, R., Ahmad, G., Esteves, S. C., \& Agarwal, A. (2016). Terminal deoxynucleotidyl transferase dUTP nick end labeling (TUNEL) assay using bench top flow cytometer for evaluation of sperm DNA fragmentation in fertility laboratories: Protocol, reference values, and quality control. Journal of Assisted Reproduction and Genetics, 33(2), 291-300. https://doi.org/10.1007/s10815-015-0635-7

Sharma, R., Gupta, S., Henkel, R., \& Agarwal, A. (2019). Critical evaluation of two models of flow cytometers for the assessment of sperm DNA fragmentation: An appeal for performance verification. Asian Journal of Andrology, 21, 438-444.

Sharma, R. K., Sabanegh, E., Mahfouz, R., Gupta, S., Thiyagarajan, A., \& Agarwal, A. (2010). TUNEL as a test for sperm DNA damage in the evaluation of male infertility. Urology, 76(6), 1380-1386. https://doi. org/10.1016/j.urology.2010.04.036

Shen, H.-M., \& Ong, C.-N. (2000). Detection of oxidative DNA damage in human sperm and its association with sperm function and male infertility. Free Radical Biology and Medicine, 28(4), 529-536. https:// doi.org/10.1016/S0891-5849(99)00234-8

Siddhartha, N., Reddy, N. S., Pandurangi, M., Muthusamy, T., Vembu, R., \& Kasinathan, K. (2019). The effect of sperm DNA fragmentation index on the outcome of intrauterine insemination and intracytoplasmic sperm injection. Journal of Human Reproductive Sciences, 12, 189-198.

Simon, L., Aston, K. I., Emery, B. R., Hotaling, J., \& Carrell, D. T. (2017). Sperm DNA damage output parameters measured by the alkaline Comet assay and their importance. Andrologia, 49, e12608.

Simon, L., Brunborg, G., Stevenson, M., Lutton, D., McManus, J., \& Lewis, S. E. (2010). Clinical significance of sperm DNA 
damage in assisted reproduction outcome. Human Reproduction, 25, 1594-1608.

Simon, L., Lutton, D., McManus, J., \& Lewis, S. E. M. (2011). Sperm DNA damage measured by the alkaline Comet assay as an independent predictor of male infertility and in vitro fertilization success. Fertility and Sterility, 95(2), 652-657. https://doi.org/10.1016/j.fertn stert.2010.08.019

Simon, L., Proutski, I., Stevenson, M., Jennings, D., McManus, J., Lutton, D., \& Lewis, S. E. (2013). Sperm DNA damage has a negative association with live-birth rates after IVF. Reprod Biomed Online, 26, 68-78.

Simon, L., Zini, A., Dyachenko, A., Ciampi, A., \& Carrell, D. (2017). A systematic review and meta-analysis to determine the effect of sperm DNA damage on in vitro fertilization and intracytoplasmic sperm injection outcome. Asian Journal of Andrology, 19(1), 80-90. https://doi. org/10.4103/1008-682x.182822

Singh, N. P., Danner, D. B., Tice, R. R., McCoy, M. T., Collins, G. D., \& Schneider, E. L. (1989). Abundant alkali-sensitive sites in DNA of human and mouse sperm. Experimental Cell Research, 184(2), 461470. https://doi.org/10.1016/0014-4827(89)90344-3

Steele, E. K., McClure, N., Maxwell, R. J., \& Lewis, S. E. (1999). A comparison of DNA damage in testicular and proximal epididymal spermatozoa in obstructive azoospermia. Molecular Human Reproduction, 5(9), 831-835.

Sugihara, A., Van Avermaete, F., Roelant, E., Punjabi, U., \& De Neubourg, D. (2020). The role of sperm DNA fragmentation testing in predicting intra-uterine insemination outcome: A systematic review and meta-analysis. European Journal of Obstetrics, Gynecology, and Reproductive Biology, 244, 8-15.

Sun, J.-G., Jurisicova, A., \& Casper, R. F. (1997). Detection of deoxyribonucleic acid fragmentation in human sperm: Correlation with fertilization in vitro. Biology of Reproduction, 56(3), 602-607.

Sun, T. C., Zhang, Y., Li, H. T., Liu, X. M., Yi, D. X., Tian, L., \& Liu, Y. X. (2018). Sperm DNA fragmentation index, as measured by sperm chromatin dispersion, might not predict assisted reproductive outcome. Taiwanese Journal of Obstetrics \& Gynecology, 57, 493-498.

Talebi, A. R., Moein, M. R., Tabibnejad, N., \& Ghasemzadeh, J. (2008). Effect of varicocele on chromatin condensation and DNA integrity of ejaculated spermatozoa using cytochemical tests. Andrologia, 40(4), 245-251. https://doi.org/10.1111/j.1439-0272.2008.00852.x

Tandara, M., Bajic, A., Tandara, L., Bilic-Zulle, L., Sunj, M., Kozina, V., ... Jukic, M. (2014). Sperm DNA integrity testing: Big halo is a good predictor of embryo quality and pregnancy after conventional IVF. Andrology, 2, 678-686.

Tarlatzis, B. C., \& Goulis, D. G. (2010). Sperm DNA fragmentation assessment: Is it really helpful? Gynecological Endocrinology, 26, 315-316.

Tarozzi, N., Nadalini, M., Stronati, A., Bizzaro, D., Dal Prato, L., Coticchio, G., \& Borini, A. (2009). Anomalies in sperm chromatin packaging: Implications for assisted reproduction techniques. Reproductive BioMedicine Online, 18, 486-495.

Tejada, R. I., Mitchell, J. C., Norman, A., Marik, J. J., \& Friedman, S. (1984). A test for the practical evaluation of male fertility by acridine orange (AO) fluorescence. Fertility and Sterility, 42, 87-91.

Telli, O., Sarici, H., Kabar, M., Ozgur, B., Resorlu, B., \& Bozkurt, S. (2015). Does varicocelectomy affect DNA fragmentation in infertile patients? Indian Journal of Urology, 31(2), 116-119. https://doi. org/10.4103/0970-1591.152811

Terquem, A., \& Dadoune, J. P. (1983). Aniline blue staining of human spermatozoon chromatin. Evaluation of nuclear maturation. In M. N. André (Ed.), The sperm cell (pp. 249-252). Dordrecht: Springer.

Tiseo, B., Esteves, S., \& Cocuzza, M. (2016). Summary evidence on the effects of varicocele treatment to improve natural fertility in subfertile men. Asian Journal of Andrology, 18(2), 239-245. https://doi. org/10.4103/1008-682x.172639
Tomlinson, M., Moffatt, O., Manicardi, G. C., Bizzaro, D., Afnan, M., \& Sakkas, D. (2001). Interrelationships between seminal parameters and sperm nuclear DNA damage before and after density gradient centrifugation: Implications for assisted conception. Human Reproduction, 16(10), 2160-2165.

Tomsu, M., Sharma, V., \& Miller, D. (2002). Embryo quality and IVF treatment outcomes may correlate with different sperm comet assay parameter. Human Reproduction, 17(7), 1856-1862.

Tremellen, K. (2008). Oxidative stress and male infertility-a clinical perspective. Human Reproduction Update, 14(3), 243-258.

Tsarev, I., Bungum, M., Giwercman, A., Erenpreisa, J., Ebessen, T., Ernst, E., \& Erenpreiss, J. (2009). Evaluation of male fertility potential by Toluidine Blue test for sperm chromatin structure assessment. Human Reproduction, 24(7), 1569-1574. https://doi.org/10.1093/ humrep/dep068

Twigg, J., Fulton, N., Gomez, E., Irvine, D. S., \& Aitken, R. J. (1998). Analysis of the impact of intracellular reactive oxygen species generation on the structural and functional integrity of human spermatozoa: Lipid peroxidation, DNA fragmentation and effectiveness of antioxidants. Human Reproduction, 13, 1429-1436.

Van de Kerckhove, F. W. R. C., De Croo, I., Gerris, J., Vanden Abbeel, E., \& De Sutter, P. (2016). Sperm chromatin dispersion test before sperm preparation is predictive of clinical pregnancy in cases of unexplained infertility treated with intrauterine insemination and induction with clomiphene citrate. Frontiers in Medicine, 3, 63. https:// doi.org/10.3389/fmed.2016.00063

van Kooij, R. J., de Boer, P., de Vreeden-Elbertse, J. M. T., Ganga, N. A., Singh, N., \& te Velde, E. R. (2004). The neutral comet assay detects double strand DNA damage in selected and unselected human spermatozoa of normospermic donors. International Journal of Andrology, 27, 140-146.

Velez de la Calle, J. F., Muller, A., Walschaerts, M., Clavere, J. L., Jimenez, C., Wittemer, C., \& Thonneau, P. (2008). Sperm deoxyribonucleic acid fragmentation as assessed by the sperm chromatin dispersion test in assisted reproductive technology programs: Results of a large prospective multicenter study. Fertility and Sterility, 90(5), 1792-1799. https://doi.org/10.1016/j.fertnstert.2007.09.021

Venkatesh, S., Thilagavathi, J., Kumar, K., Deka, D., Talwar, P., \& Dada, R. (2011). Cytogenetic, Y chromosome microdeletion, sperm chromatin and oxidative stress analysis in male partners of couples experiencing recurrent spontaneous abortions. Archives of Gynecology and Obstetrics, 284, 1577-1584.

Virant-Klun, I., Tomazevic, T., \& Meden-Vrtovec, H. (2002). Sperm single-stranded DNA, detected by acridine orange staining, reduces fertilization and quality of ICSI-derived embryos. Journal of Assisted Reproduction and Genetics, 19(7), 319-328. https://doi. org/10.1023/A:1016006509036

Virro, M. R., Larson-Cook, K. L., \& Evenson, D. P. (2004). Sperm chromatin structure assay $(\mathrm{SCSA} \otimes)$ parameters are related to fertilization, blastocyst development, and ongoing pregnancy in in vitro fertilization and intracytoplasmic sperm injection cycles. Fertility and Sterility, 81, 1289-1295.

Vogiatzi, P., Chrelias, C., Cahill, D. J., Creatsa, M., Vrachnis, N., Iliodromiti, Z., \& Kassanos, D. (2013). Siristatidis C (2013); Hemizona assay and sperm penetration assay in the prediction of IVF outcome: A systematic review. BioMed Research International, 2013, 945825. https://doi. org/10.1155/2013/945825

Wang, Y.-J., Zhang, R.-Q., Lin, Y.-J., Zhang, R.-G., \& Zhang, W.-L. (2012). Relationship between varicocele and sperm DNA damage and the effect of varicocele repair: A meta-analysis. Reproductive BioMedicine Online, 25(3), 307-314. https://doi.org/10.1016/j.rbmo.2012.05.002

Ward, W. S. (2010). Function of sperm chromatin structural elements in fertilization and development. Molecular Human Reproduction, 16, 30-36. 
Werthman, P., Wixon, R., Kasperson, K., \& Evenson, D. P. (2008). Significant decrease in sperm deoxyribonucleic acid fragmentation after varicocelectomy. Fertility and Sterility, 90(5), 1800-1804. https://doi.org/10.1016/j.fertnstert.2006.09.019

Wiweko, B., \& Utami, P. (2017). Predictive value of sperm deoxyribonucleic acid (DNA) fragmentation index in male infertility. Basic and Clinical Andrology, 27(1), 1. https://doi.org/10.1186/s1261 0-016-0046-3

Wong, A., Chuan, S. S., Patton, W. C., Jacobson, J. D., Corselli, J., \& Chan, P. J. (2008). Addition of eosin to the aniline blue assay to enhance detection of immature sperm histones. Fertility and Sterility, 90(5), 1999-2002. https://doi.org/10.1016/j.fertnstert.2007.09.026

World Health Organization (2010). WHO laboratory manual for the examination and processing of human semen (5th ed.). Geneva, Switzerland: WHO Press.

Zhang, L.-H., Qiu, Y., Wang, K.-H., Wang, Q., Tao, G., \& Wang, L.-G. (2010). Measurement of sperm DNA fragmentation using bright-field microscopy: Comparison between sperm chromatin dispersion test and terminal uridine nick-end labeling assay. Fertility and Sterility, 94(3), 1027-1032. https://doi.org/10.1016/j.fertnstert.2009.04.034

Zhang, Z., Zhu, L., Jiang, H., Chen, H., Chen, Y., \& Dai, Y. (2015). Sperm DNA fragmentation index and pregnancy outcome after IVF or ICSI: A meta-analysis. Journal of Assisted Reproduction and Genetics, 32, 17-26.

Zhao, J., Zhang, Q., Wang, Y., \& Li, Y. (2014). Whether sperm deoxyribonucleic acid fragmentation has an effect on pregnancy and miscarriage after in vitro fertilization/intracytoplasmic sperm injection: A systematic review and meta-analysis. Fertility and Sterility, 102(4), 998-1005.e1008. https://doi.org/10.1016/j.fertnstert.2014.06.033

Zhao, M., Shirley, C. R., Hayashi, S., Marcon, L., Mohapatra, B., Suganuma, R., ... Meistrich, M. L. (2004). Transition nuclear proteins are required for normal chromatin condensation and functional sperm development. Genesis, 38, 200-213.

Zini, A. (2011). Are sperm chromatin and DNA defects relevant in the clinic? Systems Biology in Reproductive Medicine, 57(1-2), 78-85. https://doi.org/10.3109/19396368.2010.515704

Zini, A., Bielecki, R., Phang, D., \& Zenzes, M. T. (2001). Correlations between two markers of sperm DNA integrity, DNA denaturation and DNA fragmentation, in fertile and infertile men. Fertility and Sterility, 75(4), 674-677.

Zini, A., Blumenfeld, A., Libman, J., \& Willis, J. (2005). Beneficial effect of microsurgical varicocelectomy on human sperm DNA integrity. Human Reproduction, 20(4), 1018-1021. https://doi.org/10.1093/ humrep/deh701

Zini, A., Fischer, M. A., Sharir, S., Shayegan, B., Phang, D., \& Jarvi, K. (2002). Prevalence of abnormal sperm DNA denaturation in fertile and infertile men. Urology, 60(6), 1069-1072.

Zini, A., Nam, R. K., Mak, V., Phang, D., \& Jarvi, K. (2000). Influence of initial semen quality on the integrity of human sperm DNA following semen processing. Fertility and Sterility, 74(4), 824-827. https://doi. org/10.1016/S0015-0282(00)01495-3

How to cite this article: Dutta S, Henkel R, Agarwal A. Comparative analysis of tests used to assess sperm chromatin integrity and DNA fragmentation. Andrologia. 2021;53:e13718. https://doi.org/10.1111/and.13718 